\title{
ANALISIS EFISIENSI PASAR VALUTA ASING DI LIMA NEGARA ASIA MENGG UNAKAN UJI KOINTEGRASI
}

\author{
Hariyadi R amelan* )
}

A danya krisis mata uang di beberapa negara A sia (Singapore, Korea, M alaysia, Thailand dan Indonesia), yang selama ini dikenal sebagai " $M$ acan A sia", telah menimbulkan konsekuensi pada penurunan yang signifikan dalam kinerja perekonomian negara-negaratersebut. D i pasar valuta asing, proses depresiasi yang berlebihan dari mata uang regional seperti Rupiah dan Ringgit $M$ al aysia terhadap mata uang utama (US D ollar) telah menimbulkan efek penularan yang berimplikasi pada semakin rentannya sistem finansial di beberapa wilayah A sia. Kondisi ini juga melahirkan fenomena bagi pelaku pasar yakni apakah krisis A sia merupakan pencerminan dari adanya inefisiensi di pasar valuta asing.

Tujuan dari paper ini menganalisis keberadaan pasar valas yang efisien di 5 negara A sia yakni (Indonesia, M alaysia, Singapura, H ongkong dan Jepang) selama 2 tahun pada periodesebelum krisis hingga saat krisis (1 A pril 1996 s.d 12 Juni 1998). A dapun jenis pasar valas yang dianalisis adalah pasar spot dan forward dengan menggunakan tiga hipotesis dasar yang menentukan pembentukan nilai tukar spot masa datang, yakni Random WalkH ypothesis (RWH ), U nbiased Forward RateH ypothesis (U FH), dan Composite Efficiency $\mathrm{H}$ ypothesis (CEH). A dapun prosedur uji yang dilakukan adalah melalui uji kointegrasi dengan menerapkan teknik EngleG ranger dan Johansen M aximum Likehood.

$\mathrm{H}$ asil uji kointegrasi menggunakan EngleGranger menunjukkan hanya H ongkong D ollar yang menunjukkan adanya signifikansi keterkaitan hubungan jangka panjang (kointegrasi) antara nilai spot dan forward. Sementara itu hasil uji kointegrasi menggunakan prosedur Johansen juga menunjukkan adanya kointegrasi padamatauang $\mathrm{H}$ ong Kong D ollar. Bukti lebih lanjut adanya kointegrasi di pasar valas H ongkong adalah terbentuknya fungsi mekanismekoreksi error yang konsisten (Error Correction M echanism) yang ditandai oleh nilai koefisien al pha yang negatif.

Untukmendukung hasil anal isis kuantitatifjuga dilakukan analisis grafisyang menjelaskan hubungan antaranilai Forward sebagai U nbiased Predictor dengan nilai spot masamendatang. secara dini kemungkinan terjadi krisis di suatu negara dan mencegah terjadinya contagion effect.

\footnotetext{
*) Hariyadi Ramelan : Dealer pada Kelompok Forex di Dealing Room, Urusan Devisa, Bank Indonesia, Email : hariyadi_ramelan@hotmail.com
} 


\section{Pendahuluan}

P

asar valuta asing (valas) dapat didefinisikan sebagai satu bentuk pasar keuangan dimana mata uang asing diperdagangkan atau dipertukarkan satu sama lain.

Pelaku pasar yang terlibat aktif dalam pasar valas antara lain perusahaan multinasional yang bertindak sebagai eksportir/ importir (MNC), fund managers, brokers, foreign exchange deal ers dari bank devisa maupun bank sentral. Perkembangan pasar valuta asing (valas) dunia, dalam dekadeterakhir ini telah menunjukkan suatu peningkatan yang sangat signifikan baik ditinjau dari volumetransaksi, jumlah partisipan serta jenis produk inovatif yang dihasilkannya. Terciptanya kondisi tersebut antara lain dimungkinkan oleh adanya teknologi pendukung dan jaringan komunikasi yang canggih (antara lain :Reuters, Telerate, Bloomberg yang merupakan penyedia utama sistem informasi nilai tukar dan perdagangan pasar valas) serta adanya dukungan deregulasi di sektor finansial dalam upaya meningkatkan efektifitas dan efisiensi pasar itu sendiri.

Dalam prakteknya, kegiatan transaksi valas di berbagai pusat pasar valas dunia berlangsung nonstop 24 jam dalam sehari. Berawal dari Auckland, Selandia baru pada pagi hari selanjutnya bergeser menuju keSydney, Tokyo, Singapore, Hong Kong, Frankfurt, Zurich, Paris, London sampai ke New York, Chicago, San Fransisco hingga terakhir di LosAngeles). Berdasarkan hasil survey dari Bank for International Settlement (BIS), volume transaksi pasar valas dunia adalah sekitar 1,26 triliun US Dollar per hari pada tahun 1995. Jumlah tersebut memberikan satu indikasi yang nyata berkaitan dengan keberadaan serta peran kunci pasar valas dalam mempengaruhi dinamika/ gejolak bisnis dan perdagangan internasional maupun regional (antara lain kawasan Asia sebagai salah satu emerging market). Tabel la dan lb menunjukkan volume transaksi di pasar valas internasional dan beberapa pusat pasar valas internasional.

Tabel 1a. Rata-rata perputaran harian transaksi di pasar valas global 1) (dalam miliar USD)

\begin{tabular}{lrrrrr}
\hline Jenis transaksi & Apr-89 & Apr-92 & $\begin{array}{l}\% \text {-age } \\
\text { Change }\end{array}$ & Apr-95 & $\begin{array}{l}\% \text {-age } \\
\text { Chanqe }\end{array}$ \\
\hline & & & & & \\
Spot transaction & 350 & 400 & 14 & 520 & 30 \\
Outright Forwards and Swaps $_{\text {Sub Total }}^{2)}$ & 240 & 420 & 75 & 670 & 60 \\
Future and Options $^{3)}$ & 590 & 820 & 39 & 1190 & 45 \\
Grand Total $^{4)}$ & 30 & 60 & 100 & 70 & 17 \\
\hline
\end{tabular}

Source : Bank for International Settlement (1996)

Note: 1) Adjusted for local and cross border double counting, except for futures and options. 2) Spot, outright forward and foreign exchange swap transactions. 3) Including OTC and exchange traded options. 4) As calculated in previous surveys 
Tabel 1b. Rata-rata perputaran harian transaksi di pasar valas dunia (dalam miliar USD)

\begin{tabular}{lrrrrr} 
Financial Centre & Apr-89 & Apr-92 & $\begin{array}{r}\%-a q e \\
\text { chanqe }\end{array}$ & Apr-95 & $\begin{array}{r}\%-a q e \\
\text { chanqe }\end{array}$ \\
United Kinqdom & 184 & 291 & 58 & 464 & 60 \\
United States & 115 & 167 & 45 & 244 & 46 \\
Japan & 111 & 120 & 8 & 161 & 34 \\
Sinqapore & 55 & 74 & 34 & 105 & 43 \\
Honq Konq & 49 & 60 & 24 & 90 & 49 \\
Switzerland & 56 & 66 & 17 & 87 & 32 \\
Germany & - & 55 & - & 76 & 39 \\
France & 23 & 33 & 44 & 58 & 74 \\
Australia & 29 & 29 & 0 & 39 & 37 \\
Denmark & 13 & 27 & 108 & 31 & 15 \\
Canada & 15 & 22 & 46 & 30 & 36 \\
Sweden & 13 & 21 & 64 & 20 & -6 \\
\hline
\end{tabular}

Source : Bank for International Settlement (1996)

Levi (1996)1) menyatakan bahwa peran pasar valas antara lain terwujud dalam pertukaran mata uang yang berbeda-beda di pasar valas internasional. Kondisi ini memberikan konsekuensi perlunya suatu nilai tukar yang rasional antar mata uang yang diperdagangkan tersebut. Adapun nilai tukar yang terbentuk akan dipengaruhi oleh perubahan banyak faktor seperti faktor fundamental, teknikal serta psikologis yang terakumulasi dalam periodetertentu. Ketiga faktor tersebut berimplikasi pada suatu kondisi nilai tukar yang cenderung fluktuatif dan penuh ketidakpastian (uncertainty of exchange rates) yang pada gilirannya akan mempengaruhi perhitungan penjualan, biaya-biaya dan keuntungan dari institusi bisnis (baik domestik maupun internasional) yang terlibat dalam aliran barang dan jasa internasional.

Eitemann et. al. (1995)2) menyatakan bahwa ada tiga fungsi utama pasar val as yaitu : pertama, fungsi perpindahan daya beli (transfer of purchasing power) dalam transaksi valas internasional; kedua, fungsi penyediaan kredit (provision of credit) untuk transaksi dagang internasional (dalam bentuk bankers acceptance ataupun Letter of $C$ redit), dan ketiga, fungsi minimasi resiko fluktuasi val as (minimizing foreign exchange risk) antara lain dalam bentuk fasilitas hedging untuk mengantisipasi resiko fluktuasi nilai tukar. Namun demikian, peran kunci pasar valas dalam transaksi internasional tersebut hanya bisa optimal dalam kondisi atau keberadaan pasar valasyang benar-benar efisien. Efisiensi yang terbentuk dalam pasar

1) Levi, Maurice (1996) International Money and Finance, New York.

2) Eiteman, et al (1995) Multinational Business Finance, New York. 
val as ini akan membawasuatu peningkatan produktivitas (pengurangan high cost transaction) yang pada akhirnya bermuara pada peningkatan pertumbuhan ekonomi secara keseluruhan.

Berkaitan dengan hal tersebut di atas, kajian efisiensi pasar keuangan telah banyak dikaji dalam literatur finansial, karena memang merupakan isu yang cukup menantang dan relatifup to date. Sebagai satu ilustrasi, John Naisbit (1995) ${ }^{3)}$ menyebutkan bahwa pertumbuhan ekonomi Asia merupakan salah satu perkembangan terpenting dunia dalam menyambut millenium ketiga. Opini ini sekaligus menggarisbawahi apayang dilaporkan oleh Bank Dunia pada tahun 19934) bahwa pertumbuhan beberapa negara di A sia dapat dijadikan contoh dan menyeru negara-negaralain yang belum maju untuk mereplikasi kebijakan-kebijakannyayang dianggap sangat positif untuk perkembangan ekonomi regional (emerging market).

Namun pada sisi yang lain, patut pula dicatat pemikiran kontroversial yang disampaikan oleh Paul Krugman ${ }^{5}$. Krugman memberikan indikasi yang sebaliknya bahwa pertumbuhan ekonomi yang relatif tinggi di beberapa negara A sia lebih merupakan mitos dan lebih didorong oleh faktor khusus (extraordinary) seperti rendahnya upah buruh dan faktor aliran modal masuk (capital inflow) dibanding oleh karena fator efisiensi produksi. Dalam perspektif Krugman, kondisi ini akan membawapadasuatu implikasi adanya bencana besar yang lebih kompleks (catasthrope).

Dari dua perspektif yang bertentangan tersebut serta dikaitkan dengan peran pasar valas dalam mempengaruhi pasar keuangan global, kiranya sangat relevan untuk mengkaji perkembangan pasar val as di beberapa negara A sia. Terlebi h lagi, adanya krisis mata uang regional yang dipicu oleh devaluasi mata uang Baht pada awal Juli 1997telah menimbulkan berbagai fenomena yang pada intinya juga mengarah pada satu fokus persoalan yakni apakah krisis mata uang Asia merupakan refleksi adanya inefisiensi di pasar valas. (lihat Tabel 1c. Kronologi terjadinya krisis mata uang Asia). Disamping itu, relevansi kedua pemikiran diatas adalah bahwa idealnya kinerja perekonomian suatu negara dapat tercermin dari indikator-indikator variabel makro yang telah disepakati secara luas. Berdasarkan Chase Research (1997), ada 5 saluran utama bahwa krisis Asia dapat mempengaruhi pasar yang lain; yaitu : (1). Pertumbuhan ekonomi, (2). Nilai tukar, (3). Kemakmuran, (4). Disinflasi dan (5). Tingkat Suku Bunga. Dalam konteksnilai tukar sebagai sal ah satu parameter, maka pergerakan nilai tukar satu mata uang yang berlebihan terhadap mata uang lain (depresiasi/ appresiasi) merupakan refleksi dari ada tidaknya efisiensi pasar valas di wilayah/ negara tertentu. Pada akhirnya, keberadaan pasar valas yang efisien dapat menjadi salah satu indikator kinerja yang riil dari perekonomian suatu negara, apakah merupakan bubbleeconomy atau bukan.

3) John Naisbitt (1996), Megatrends Asia, London.

4) World Bank (1993), The East Asian Miracle, New York

5) Paul Krugman (1997), Pop Internationalism, Cambridge, MA 
Tulisan ini melakukan studi awal tentang efisiensi pasar valas menggunakan Random Walk H ypothesis (RWH), U nbiased Forward rate H ypothesis (UFH) dan Composite Efficiency $\mathrm{H}$ ypothesis ( $\mathrm{CEH}$ ) dengan menerapkan uji kointegrasi Engle-Granger dan Johansen Maximum Likelihood terhadap pasar Spot dan Forward di lima negara Asia (Indonesia, Singapura, Malaysia, Hong Kong dan Jepang).

Pemilihan 5 negara di atas sebagai sample didasarkan pada beberapa al asan. Pertama, perlunya ketersediaan data pasar Spot dan Forward dalam rangka uji UFH dan CEH. Kedua, perlunya azas representasi dimana 2 negara (Indonesia dan Malaysia) mewakili negaranegara sedang berkembang (emerging market) yang terkena krisis sedangkan 3 negaralainnya (Jepang, Hong Kong dan Singapore) mewakili negara-negara yang relatif sudah maju dan tidak terpengaruh krisis. Adapun periodedata yang dianalisis adalah data Spot dan Forward harian dalam kisaran waktu antara 1 A pril 1996 s/ d 12 Juni 1998. Tujuan dari tulisan ini adal ah untuk melihat derajat perkembangan pasar val as di 5 negara kawasan A sia sebagai cerminan ada tidaknya integrasi antara pasar Spot dan Forward di masing-masing negara tersebut. Hipotesis yang ingin diajukan adalah bahwa bila nilai Spot dan Forward terkointegrasi (yang dibuktikan dengan hasil uji Dicky Fuller/ Augmented Dicky Fuller) maka kondisi tersebut memenuhi syarat untuk pasar valas yang efisien. Selanjutnya, bila suatu pasar valas terkointegrasi untuk jangka panjang maka akan terbentuk mekanisme koreksi error (Copeland, 1991).

Beberapa kajian tentang pasar valasyang efisien telah dilakukan oleh beberapa peneliti seperti Froot (1990), Tucker et. al. (1991), Hopper (1994), Madsen (1996), Alexis and A pergis(1996), Lajaunieet. al. (1996). Dalam jangka panjang hasil kesimpulan secara umum dari survei atau analisis tersebut diatas ternyata tidak terdapat bukti yang berlawanan dengan konsep Efficient $\mathrm{M}$ arket $\mathrm{H}$ ypothesis (EM H ), namun demikian masih terdapat beberapa variasi hasil kajian terhadap uji efisiensi pasar valas yang harus diinterpretasikan secara hati-hati mengingat faktor keterbatasan data untuk sample yang terkadang tidak mencerminkan indikasi pasar yang efisien untuk periodeyang pendek.

Froot (1990) meragukan keberadaan pasar valas yang efisien berdasarkan hasil uji yang dilakukannya bahwa ternyata nilai Forward bersifat bias sebagai alat prediksi nilai Spotmasa mendatang di pasar valas. Namun Froottidak menjelaskan al asan ketidakefisienan pasar Forward. Analisis Froot tersebut juga sejalan dengan hasil kajian Hopper (1994) untuk mata uang Canadian Dollar, dengan menekankan argumentasinya pada kegagalan konsep ekspektasi yang rasional di pasar valas hingga memungkinkan adanya exploitable extra return. Hopper juga mencatat bahwa meskipun investor tidak memiliki ekspektasi rasional ataupun terdapat risk premium yang bervariasi di antara pelaku pasar, masi h bisa memungkinkan terjadinya pasar yang efisien. 
Hasil uji yang dilakukan Tucker et.al . (1991) terhadap Canadian Dollar, French Franc, Deustche Mark dan UK Pound Sterling mengindikasikan adanya pasar valas yang efisien dan konsisten dengan konsep Random Walk Hypothesis, Unbiased Forward rateHypothesis, serta CompositeEfficiency H ypothesis. Hasil ini juga konsisten dengan apa yang diperoleh Meese and Rogoff (1983), Huang (1984) dan Chiang (1986). Hasil empiris yang cukup up to date adalah hasil uji yang dilakukan oleh A lexis dan A pergis (1996) terhadap 3 mata uang utama yakni DeustcheMark, French Franc dan Yen terhadap USDollar.

Berdasarkan hasil uji kointegrasi dapat diindikasikan bahwa pasar yang efisien sangat dipengaruhi oleh hubungan jangka panjang antara nilai Spot dan Forward. Dengan menerapkan uji tersebut, ternyata 3 mata uang tersebut menunjukkan adanya pemenuhan prasyarat efisiensi di ketiga pasar valas tersebut. Sementara itu, Lajaunie et. al. (1996) juga menggunakan mata uang Deustche Mark, Canadian Dollar, UK Pound Sterling dan Yen Jepang terhadap US Dollar di tiga pasar utama yakni Tokyo, London dan N ew York. Hasil uji Johansen yang dilakukan menunjukkan adanya hasil yang konsisten di ketiga lokasi dan sangat mendukung keberadaan pasar valas global yang efisien.

Tabel 1c. Kronologi Krisis M ata U ang A sia.

\begin{tabular}{|c|c|}
\hline \multicolumn{2}{|r|}{1997} \\
\hline Early 1997 & $\begin{array}{l}\text { Pressure on Thai baht met by heavy intervention in spot and forward } \\
\text { market. }\end{array}$ \\
\hline $15^{\text {th }}$ May & $\begin{array}{l}\text { Thailand introduces controls aimed at segmenting the onshore and } \\
\text { offshore markets but strong pressure continues. Similar measures } \\
\text { introduced in other countries at various stages in the crisis prove } \\
\text { ineffective. }\end{array}$ \\
\hline $2^{\text {nd }}$ July & $\begin{array}{l}\text { Floating of the Thai baht. Pressure spreads to the Philippine peso, } \\
\text { Malaysian ringgit and Indonesian Rupiah. }\end{array}$ \\
\hline $11^{\text {th }}$ July & $\begin{array}{l}\text { Band of the Philippine peso widened to unspecified range. Band of the } \\
\text { Indonesian Rupiah widened from } 8 \% \text { to } 12 \% \text {. }\end{array}$ \\
\hline July & Malaysian ringgit falls by $4.8 \%$ by end of July. \\
\hline August & Equity pricespeak in Hong Kong on 7 th Augustand in Taiwan on 26th A ugust. \\
\hline $14^{\text {th }}$ August & Floating of the Indonesian rupiah. \\
\hline $20^{\text {th }}$ August & IMF standing credit for Thailand of $\$ 3.9$ billion approved \\
\hline $17^{\text {th }}$ October & $\begin{array}{l}\text { Authorities stop supporting the New Taiwan dollar, which falls by } 6 \% \text {. } \\
\text { Pressure on of Hong Kong dollar and equity market intensifies. }\end{array}$ \\
\hline $20^{\text {th }}-23^{\text {rd }}$ October & $\begin{array}{l}\text { Financial turbulence in Hong Kong. Hang Seng Index falls by } 23 \% \text { in } \\
\text { three days. Pressure on Korean Won mounts. }\end{array}$ \\
\hline $28^{\text {th }}$ October & $23 \%$ ded ine in Russian equity prices. \\
\hline
\end{tabular}




\begin{tabular}{|c|c|}
\hline $5^{\text {th }}$ November & $\begin{array}{l}\text { IMF standby credit for Indonesia of } \$ 10.1 \text { billion approved; } \$ 3 \text { billion } \\
\text { made available immediately. }\end{array}$ \\
\hline $20^{\text {th }}$ November & Daily fluctuation band for the Korean won widened from $2.25 \%$ to $10 \%$. \\
\hline $21^{\text {st }}$ November & Korea applies for IMF standby credit. \\
\hline $4^{\text {th }}$ December & $\begin{array}{l}\text { IMF standby credit for Korea of a record } \$ 21 \text { billion over three years } \\
\text { approved. } \$ 5.6 \text { billion disbursed immediately. }\end{array}$ \\
\hline $16^{\text {th }}$ December & Floating of the Korean won. \\
\hline \multicolumn{2}{|r|}{1998} \\
\hline $27^{\text {th }}$ January & Indonesian corporate debt "pause" \\
\hline $29^{\text {th }}$ January & $\begin{array}{l}\text { Agreement between Korea and its external creditors to exchange } \$ 24 \\
\text { billion of short term debt for government-guaranteed loan at floating } \\
\text { rates of } 2.5 \% \text { percentage points over six month LIBOR. }\end{array}$ \\
\hline $9^{\text {th }}-10^{\text {th }}$ Feb & $\begin{array}{l}\text { Indonesia's plan to create a currency board opposed by the IMF and } \\
\text { several creditor governments, which threaten to withdraw financial } \\
\text { assistance. }\end{array}$ \\
\hline $4^{\text {th }}$ March & $\begin{array}{l}\text { in a second review of Thailand's economic programme the IMF relaxes } \\
\text { certain macro economic policy targets and approves disbursement of } \\
\text { second tranche. }\end{array}$ \\
\hline $14^{\text {th }}$ May & $\begin{array}{l}\text { Indonesian political unrest and riots in Jakarta. Rupiah fallsto Rp.11.450/ } \\
\text { US\$ }\end{array}$ \\
\hline $21^{\text {st }}$ May & $\begin{array}{l}\text { Soeharto resigned and BJ. Habibie was appointed as a new Indonesian } \\
\text { President }\end{array}$ \\
\hline $9^{\text {th }}$ June & Yen falls to lowest leve since June 1991 at 140.73 Yen/ US\$ \\
\hline $18^{\text {th }}$ June & Rupiah falls to the new lowest level at Rp.16.900/ US\$. \\
\hline
\end{tabular}

Sources: Bank for International Settlement - 68th Annual Report (1998) and various sources from Financial Times Newspaper.

\section{Kajian Teoritis Efisiensi Pasar Valas}

Pasar yang efisien, menurut Samuel son dan N ordhaus (1985) didefinisikan sebagai pasar dimana seluruh informasi dapat secara cepat dimengerti oleh seluruh peserta pasar dan tercermin dari pembentukan harga di pasar. Jika sebuah pasar efisien, harga saat ini dari suatu asset akan merefleksikan semua informasi yang tersedia sejalan dengan

6) Samuelson and Nordhaus (1985), Economics, New York. 
terbentuknya harga asset tersebut. Didalam pasar Spot dan Forward, kondisi efisien ini akan tercermin dalam persamaan sbb :

$$
E\left[S_{t+1}-S_{t+1}^{e} \mid \Omega_{t}\right]=0
$$

dimana:

$\mathrm{S}_{\mathrm{t}+1}=$ SpotRate

$\mathrm{S}_{\mathrm{t}+1}=$ Ekspektasi Spot Rate

$\Omega_{\mathrm{t}} \quad=$ Informasi yang tersedia pada saat $\mathrm{t}$

Persamaan di atas menunjukkan bahwa ekspektasi rata-rata akan $=0$ dan tidak ada peluang keuntungan yang bisa dieksploitasi oleh peserta pasar. Sejalan dengan konsep tersebut, digunakan 3 hipotesa yang umum digunakan yakni :

\section{(1) Random Walk Hypothesis (RWH).}

Pada prakteknya, investor tidak menggunakan semua informasi dan pendekatan yang paling sederhana untuk melakukan ekspektasi adalah metode random walk. Metode ini dapat dijabarkan bahwa nilai spot periode mendatang hanya dipengaruhi oleh nilai spot sekarang. Persamaannya adalah sbb :

$$
\mathrm{S}_{\mathrm{t}+1}^{\mathrm{e}}=\beta_{0}+\beta_{1} \mathrm{~S}_{\mathrm{t}}+\varepsilon_{\mathrm{t}+1}
$$

dimana :

$$
\begin{aligned}
& \mathrm{S}_{\mathrm{t}+1}=\text { Ekspektasi nilai Spot satu periodemendatang } \\
& \mathrm{S}_{\mathrm{t}}=\text { Nilai Spot sekarang } \\
& \varepsilon_{\mathrm{t}+1}=\text { Error } \\
& \beta_{0}, \beta_{1}=\text { Koefisien; dimana } \mathrm{H}_{0}: \beta_{0}=0 \text { dan } \beta_{1}=1
\end{aligned}
$$

Jika pasar Spot efisien maka pasar berperilaku mengikuti random walk, maka nilai nyata Spot akan bergerak secara random dalam keseimbangan yang konstan (bernilai $=0$ secara rata-rata), jadi tidak ada excess profit yang dapat dieksploitasi melalui arbitrase.

\section{(2) U nbiased Forward rate Hypothesis (UFH).}

Selain Random Walk, juga dimungkinkan untuk menggunakan nilai Forward sebagai indikator untuk mengukur nilai spot periode mendatang. Bila nilai Forward digunakan sebagai unbiased predictor dari nilai Spot periode mendatang, maka nilai Forward dapat overestimates maupun underestimates sepanjang periodetertentu dengan jumlah dan frekuensi yang relatif sama, hingga totalnya $=0$ (Gambar 1$)$. Kondisi ini bisa dijabarkan dengan persamaan sbb: 


$$
\mathrm{S}_{\mathrm{t}+1}^{\mathrm{e}}=\beta_{0}+\beta_{2} \mathrm{~F}_{\mathrm{t}}+\varepsilon_{\mathrm{t}+1}
$$

dimana :

$$
\begin{aligned}
& \mathrm{S}_{\mathrm{t}+1}^{\mathrm{e}}=\text { Ekspektasi nilai Spot satu periodemendatang } \\
& \mathrm{F}_{\mathrm{t}}=\text { Nilai Forward sekarang } \\
& \varepsilon_{\mathrm{t}+1}=\text { Error } \\
& \beta_{0}, \beta_{2}=\text { Koefisien; dimana } \mathrm{H}_{0}: \beta_{0}=0 \text { dan } \beta_{2}=1
\end{aligned}
$$

\section{G ambar 1. Forward Rate as an Unbiased Predictor of Future Spot Rate}

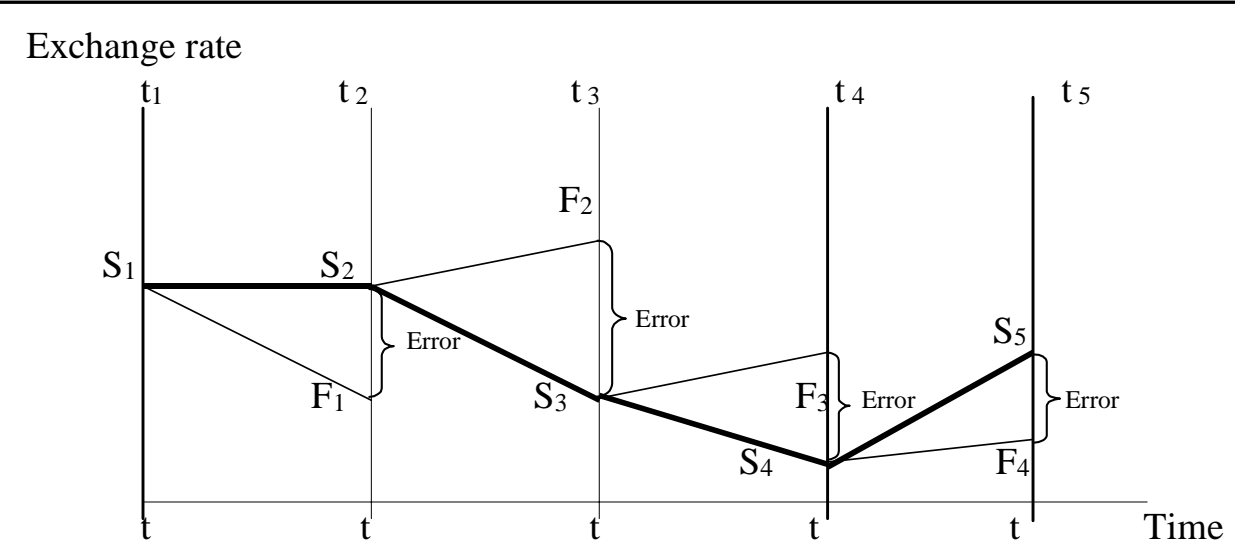

Source : Eitman, et al (1996)

\section{(3) Composite Efficiency Hypothesis (CEH)}

Hipotesa ini secara ringkas merupakan gabungan dari dua hipotesa sebel umnya, jadi nilai spot periodemendatang akan dipengaruhi oleh nilai spot dan forward saat ini secara simultan. Kondisi ini dapat dijabarkan dalam persamaan sbb :

$$
\mathrm{S}_{\mathrm{t}+1}^{\mathrm{e}}=\beta_{0}+\beta_{1} \mathrm{~S}_{\mathrm{t}}+\beta_{2} \mathrm{~F}_{\mathrm{t}}+\varepsilon_{\mathrm{t}+1}
$$

dimana :

$$
\begin{array}{ll}
\mathrm{S}_{\mathrm{t}+1}^{\mathrm{e}} & =\text { Ekspektasi nilai Spot satu periode mendatang } \\
\mathrm{S}_{\mathrm{t}} & =\text { Nilai Spot sekarang } \\
\mathrm{F}_{\mathrm{t}} & =\text { Nilai Forward sekarang } \\
\varepsilon_{\mathrm{t}+1} & =\text { Error } \\
\beta_{0}, \beta_{1}, \beta_{2} & =\text { Koefisien dimana } \beta_{0}=0 \text { dan } \beta_{1}+\beta_{2}=1
\end{array}
$$




\section{Kointegrasi Pasar Valas}

Konsep hipotesis pasar yang efisien (efficient market hypothesis) pada dasarnya berupaya untuk menjelaskan adanya hubungan yang saling terkait antara nilai Spot dan Forward saat ini untuk memprediksi nilai Spot satu periodemendatang. Dengan kata lain, pasar yang efisien harus memiliki atau mengandung adanya kointegrasi antar faktor (variabel) yang ada. Untuk menguji hipotesis pasar yang efisien tulisan ini menggunakan konsep kointegrasi yang diperkenalkan oleh Granger (1983), Granger - Weiss (1983) serta Engle- Granger (1987) ${ }^{7}$. Dalam konsep ini, 2 atau lebih variabel (series) non stasioner akan terkointegrasi bila kombinasinya juga linear sejalan dengan berjalannya waktu, meskipun bisa terjadi masing-masing variabel nya bersifat non stasioner. Bila variabel (series) tersebut terkointegrasi maka terdapat hubungan yang stabil dalam jangka panjang. Sebaliknya, bila tidak terdapat kointegrasi antar variabel (series) maka berimplikasi tidak adanya keterkaitan hubungan dalamjangka panjang. Perlu ditambahkan bahwa uji kointegrasi yang digunakan dalam tulisan ini adalah uji kointegrasi untuk hubungan antar variable yang linier.

Selanjutnya berdasarkan Representative Theory Engle- Granger , bila dua seri non stasioner yang terdiri atas $\mathrm{S}_{\mathrm{t}}$ dan $\mathrm{F}_{\mathrm{t}}$ terkointegrasi, maka akan ada representasi yang khusus sbb:

$$
\mathrm{S}_{\mathrm{t}=\beta_{0}}+\beta_{1} \mathrm{~F}_{\mathrm{t}}+\mathrm{u}_{\mathrm{t}}
$$

sedemikian rupa hingga $u_{t}$ (error term) stasioner, I (0). Selanjutnya apabila $S_{t}$ dan $F_{t}$ keduanya $\mathrm{I}(1)$ namun $\mathrm{u}_{\mathrm{t}} \mathrm{l}(0)$ maka harus ada proses peyesuaian yang dinamis yang disebut mekanisme koreksi error (Error Correction M echanism/ECM ), yang dijabarkan dalam bentuk:

$$
\Delta \mathrm{S}_{\mathrm{t}}=\alpha\left(\mathrm{S}_{\mathrm{t}}-\mathrm{F}_{\mathrm{t}-\mathrm{n}}\right)_{\mathrm{t}-1}+\beta_{0} \Delta \mathrm{F}_{\mathrm{t}}+\sum_{\mathrm{k}=1}^{\mathrm{n}} \beta_{\mathrm{k}} \Delta \mathrm{S}_{\mathrm{t}-\mathrm{k}}+\sum_{\mathrm{k}=1}^{\mathrm{n}} \beta_{\mathrm{k}} \Delta \mathrm{F}_{\mathrm{t}-\mathrm{k}}+\varepsilon_{\mathrm{t}}
$$

dimana :

$\left(\mathrm{S}_{\mathrm{t}}-\mathrm{F}_{\mathrm{t}-\mathrm{n}}\right)_{\mathrm{t}-1}=$ Lagged hubungan jangka panjang dari regresi kointegratif dalam hal ini, $\mathrm{n}=66$.

$\mathrm{S}_{\mathrm{t}-\mathrm{k}}, \mathrm{F}_{\mathrm{t}-\mathrm{k}}=$ Nilai logaritmik perubahan nilai Spot/ Forward

$\varepsilon_{\mathrm{t}} \quad=$ Error (tidak ada korelasi serial)

$\alpha, \beta_{0}, \beta_{\mathrm{k}}=$ Koefisien, dimana $\mathrm{a}<0$ (negativesign)

Persamaan ECM pertamakali dihitung dengan menggunakan 10 lags $\mathrm{D}\left(\mathrm{S}_{\mathrm{t}}\right)$ dan $\mathrm{D}\left(\mathrm{F}_{\mathrm{t}}\right)$, kemudian dengan secara berurutan lags yang signifikan dimasukkan kedalam model hingga menghasilkan persamaan ECM yang menghasilkan tandakoefisien al phayang negatif. Tanda negatif tersebut berarti terdapat pengaruh yang signifikan pada mekanismekoreksi error.

7) Engle, R.F and C.W.J. Granger (1987), Cointegration and Error Correction : Representation Estimation and Testing. Econometrica, 55 pp.251 -76. 
Dua prosedur yang umum digunakan dalan uji kointegrasi adalah Engle-Granger dan Johansen(Johansen Maximum Likelihood). Padadasarnya, uji kointegrasi meliputi 3langkahyakni:

(1) Uji integrasi untuk masing-masing variabel dengan menggunakan unit root analysis.

(2) Uji Kointegrasi menggunakan Engle-Granger ataupun Johansen Procedure.

(3) Estimasi dengan regresi.

Keseluruhan teknis perhitungan diatas dilakukan dengan Eviews Software, sedangkan untuk pengujian tidak adanya korel asi antar residu (error) digunakan LM Test. Prosedur analisis dalam kajian ini dapat dilihat pada Lampiran Prosedur A nalisis.

\section{Analisis Kualitatif dan Kuantitatif}

\section{(1) Analisis Kualitatif (Grafis)}

Data yang dianalisis adalah data harian Spot dan Forward yang berawal dari saat sebelum krisis (1 A pril 1996) s/ d saat krisis (12 Juni 1998). Istilah (notasi) yang digunakan untuk masing-masing data adalah sbb :

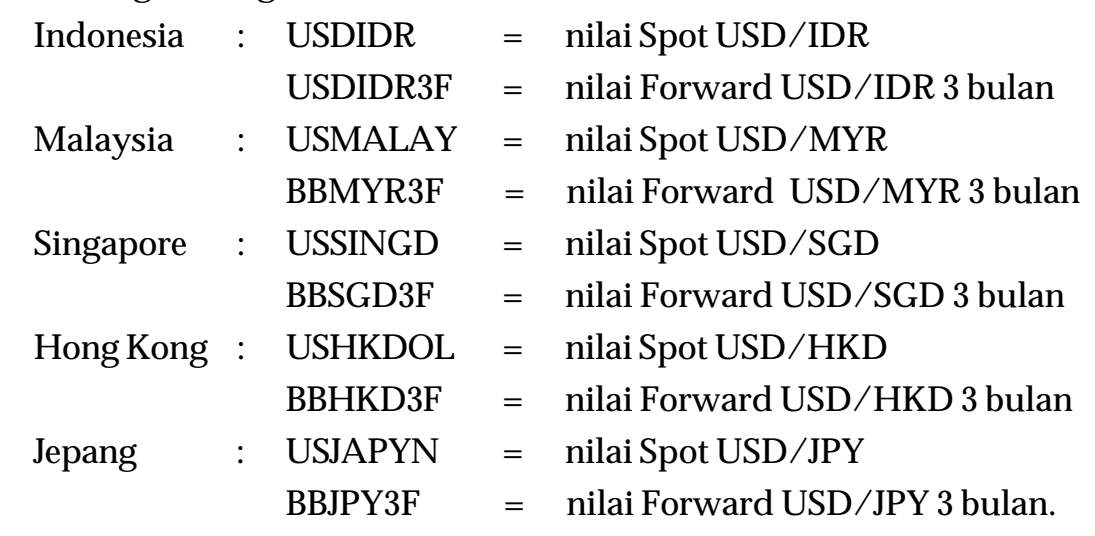

Nilai Forward yang digunakan untuk jangka waktu 3 bulan atau sama dengan 66 hari, dengan asumsi bahwa dalam praktek di pasar val as internasional satu bulan terdiri atas 22 hari. Jadi dalam uji kointegrasi , maka nilai spot sekarang adalah sama dengan nilai Forward pada saat (t-66). Berdasarkan asumsi tersebut, dapat dikonstruksikan grafik perkembangan nilai Spot aktual (St) dengan prediksi nilai Spot yang didasarkan dari nilai Forward pada 3 bulan sebelumnya $\left(\mathrm{F}_{\mathrm{t}-6 \mathrm{6}}\right)$. Secara teoritis seharusnya nilai forward tersebut akan mencerminkan nilai spot yang aktual.

Dari G ambar 2, terlihat bahwa nilai Spot Rupiah terhadap US Dollar relatif stabil dari periodeawal Januari 1996 sampai menjelang krisis pada awal Juli 1997 (saat terjadinya devaluasi BahtThailand) . Bahkan pada periodetersebut nilai Spot Rupiah sempat menguat terhadap USDollar yang ditunjukkan dari grafik nilai Forward(t-66) yang overestimate (berada di atas grafik nilai aktual Spot atau nilai Rupiah cenderung apresiatif). Namun demikian , 
semenjak krisis bulan Juli 1997 kondisi sebaliknya yang terjadi. Grafik nilai Forward (t-66) menunjukkan nilai yang underestimate terhadap nilai Spot aktual (nilai Rupiah cenderung depresiatif). Adapun total depresiasi nilai Rupiah terhadap USDollar selama periodeanalisis adalah sekitar 477\%, yakni dari Rp 2,338 per USD pada tanggal 1 A pril 1996 menjadi Rp 13,500 per USD pada tanggal 12 Juni 1998.

Dari Gambar 3, terlihat bahwa sebelum terjadinya krisis pada bulan Juli 1997, nilai Spot Ringgit Malaysia terhadap USDollar juga menunjukkan pergerakan yang relatif stabil, meskipun prediksi nilai Spotyang ditunjukkan dari nilai Forward (t-66) terkadang overestimate ataupun underestimate. Sementara pada periode saat krisis nampak bahwa nilai Forward (t66) cenderung underestimate terhadap nilai Spot aktual pada periode yang sama. Secara keseluruhan, nilai MYR terdepresiasi sebesar 59.6\%, yakni dari MYR 1.1996 per USD pada tanggal 1 A pril 1996 menjadi 4,043 MYR per USD pada tanggal 12Juni 1998.

Dari Gambar 4, terlihat bahwa nilai Spot Dollar Singaporejuga relatif stabil terhadap USDollar pada periodesebelum krisis. Hal ini ditunjukkan oleh nilai Forward (t-66) yang relatif tidak overestimate terhadap nilai Spot pada periode yang sama. Sementara pada periode saat krisisnilai Forward (t-66) cenderung underestimateterhadap nilai Spotaktual. Secarakeseluruhan, nilai Dollar Singapore juga turut terdepresiasi sebesar 23\%, yakni dari SGD 1.4065 per USD pada tanggal 1 A pril 1996 menjadi SGD 1.7470 per USD pada tanggal 12 Juni 1998.

Sementara itu pada $\mathbf{G}$ ambar 5, terlihat bahwa pada periodesebel um krisis nilai Spot Hong Kong Dollar cenderung stabil sepanjang periode analisis. Bahkan pada saat krisis nilai Forward (t-66) cenderung over estimate terhadap nilai Spot aktual. Secara keseluruhan Dollar Hong Kong hanyaterdepresiasi sebesar 0.18\%, yakni dari HKD 7.7341 per USD pada tanggal 1 A pril 1996 menjadi HKD 7.7482 per USD pada tanggal 12 Juni 1998. Hal ini sekaligus mengindikasikan bahwa Hong Kong Dollar relatif stabil terhadap USDollar dan relatif tidak terkena dampak krisis Asia.

Pada G ambar 6 menunjukkan bahwa nilai SpotYen Jepang relatif stabil terhadap US Dollar sepanjang periode analisis, meskipun ada kecenderungan nilai Forward (t-66) underestimateterhadap nilai Spotaktual. Total depresiasi nilai Yen terhadap USDollar sebesar 33\%, yakni dari Yen 107.59 per USD pada tanggal 1A pril 1996menjadi Yen 143.98 per USD pada tanggal 12 Juni 1998. 
Figure 2c. The Actual and Forecast Spot Rate of Indonesian Rupiah against US Dollar (1996 - 1998)

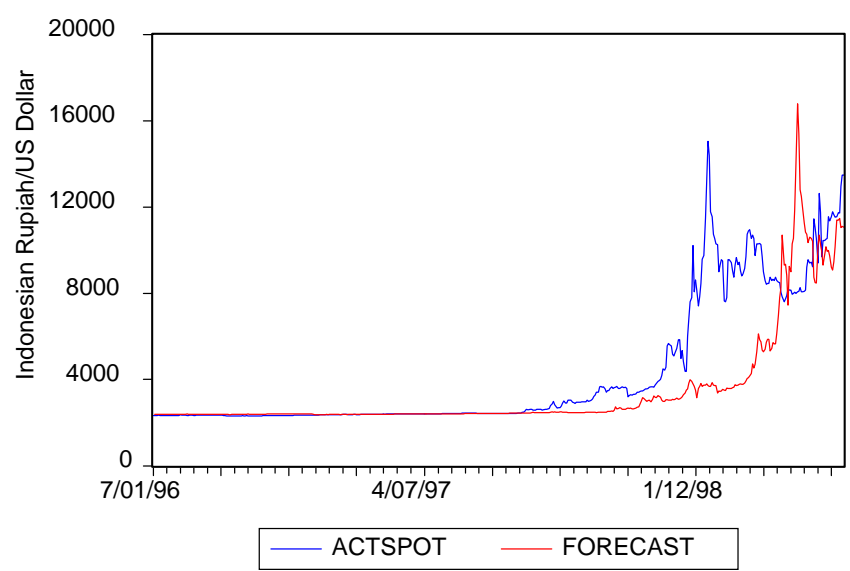

Figure 2d. The Actual and Forecast Spot Rate of Indonesian Rupiah against US Dollar (1996 - 1997)

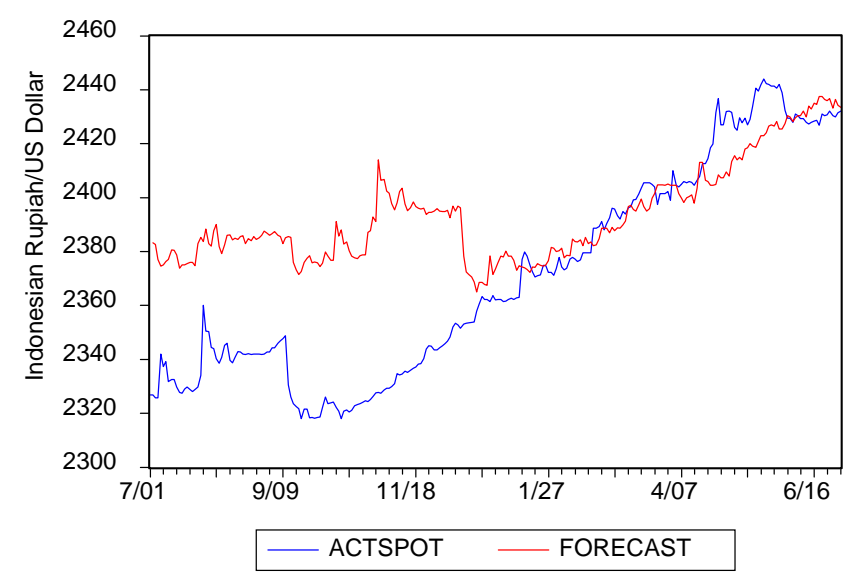

Figure 2e. The Actual and Forecast Spot Rate of Indonesian Rupiah against US Dollar (1997 - 1998)

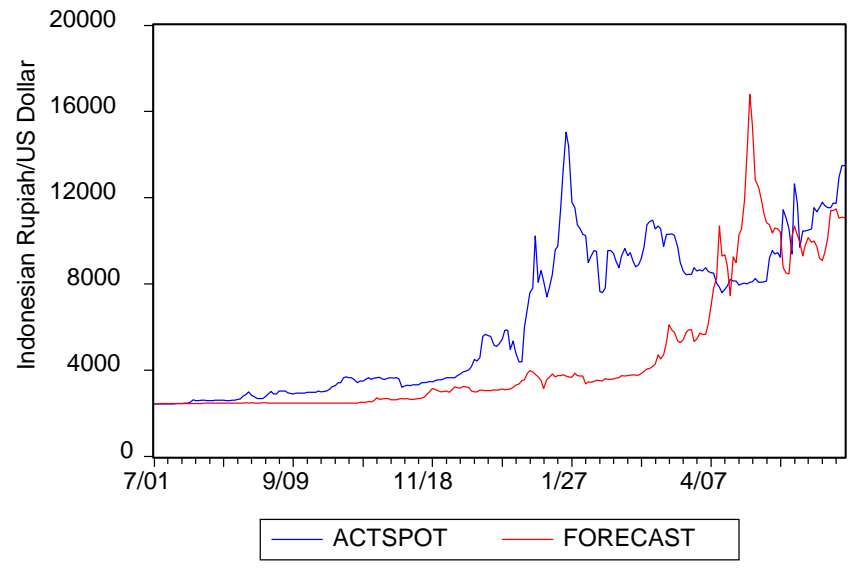


Figure 3c. The Actual and Forecast Spot Rate of Malaysian Ringgit against US Dollar (1996 - 1998)

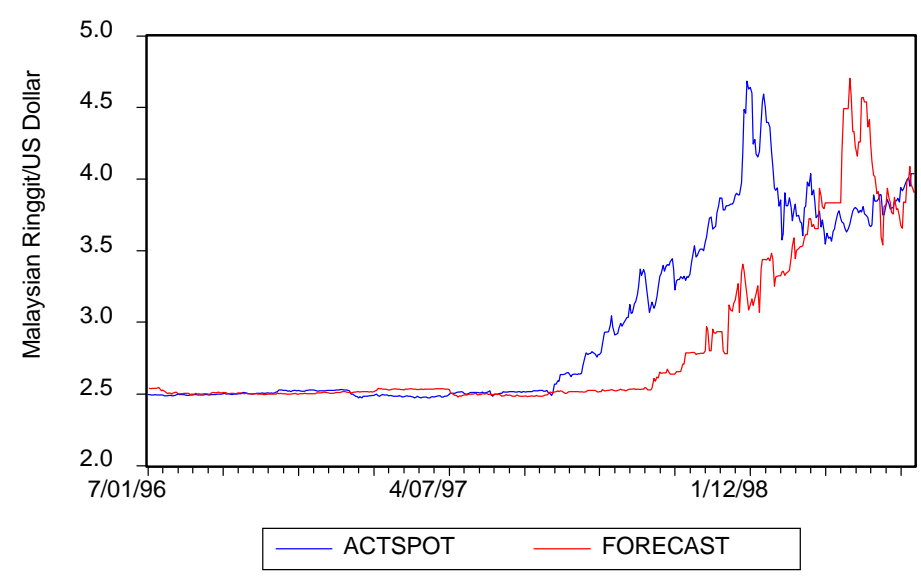

Figure 3d. The Actual and Forecast Spot Rate of Malaysian Ringgit against US Dollar (1996 - 1997)

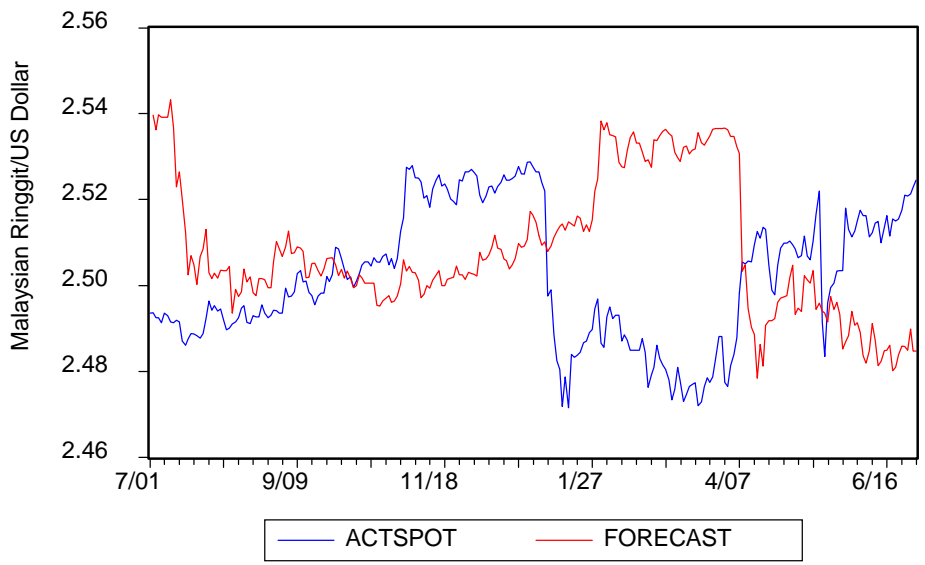

Figure 3e. The Actual and Forecast Spot Rate of Malysian Ringgit against US Dollar (1997 - 1998)

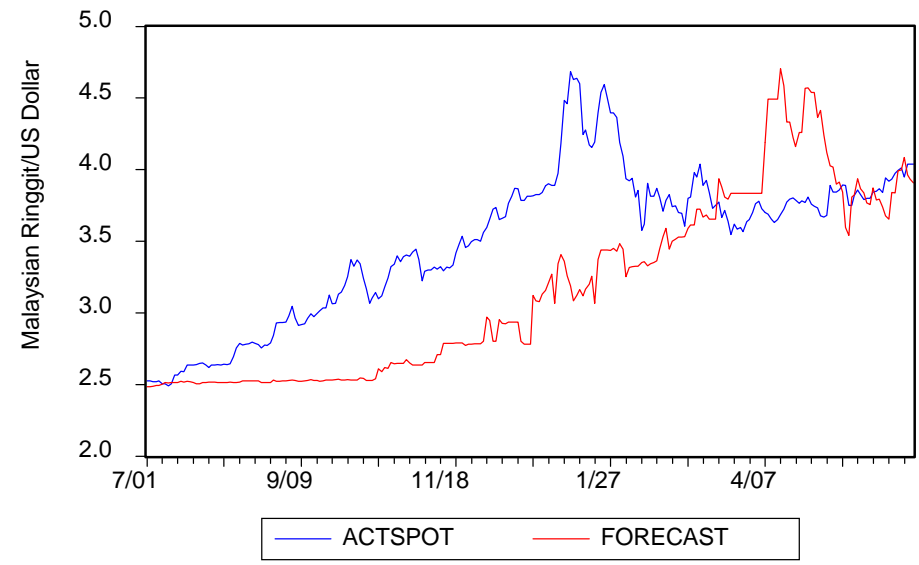


Figure 4c. The Actual and Forecast Spot Rate of Singapore Dollar against US Dollar (1996 - 1998)

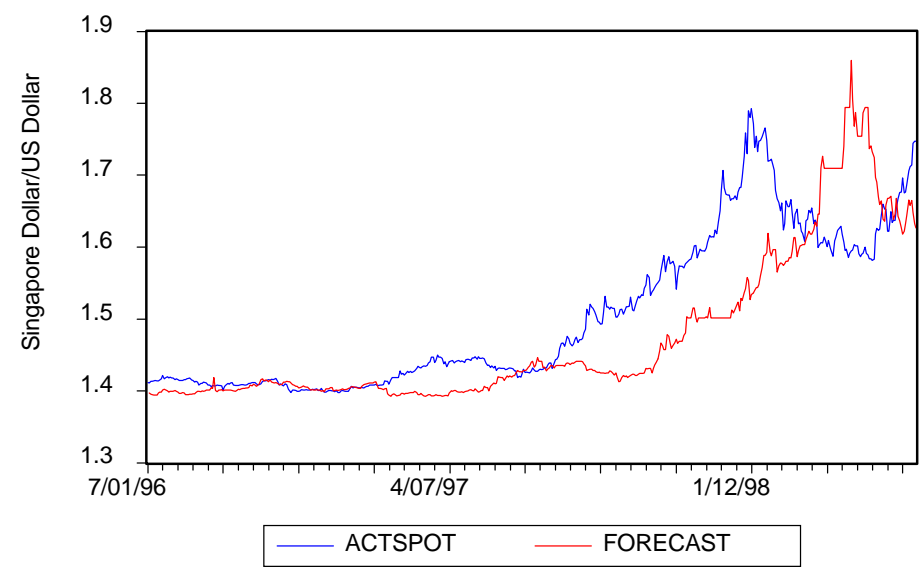

Figure 4d. The Actual and Forecast Spot Rate of Singapore Dollar against US Dollar (1996 - 1997)

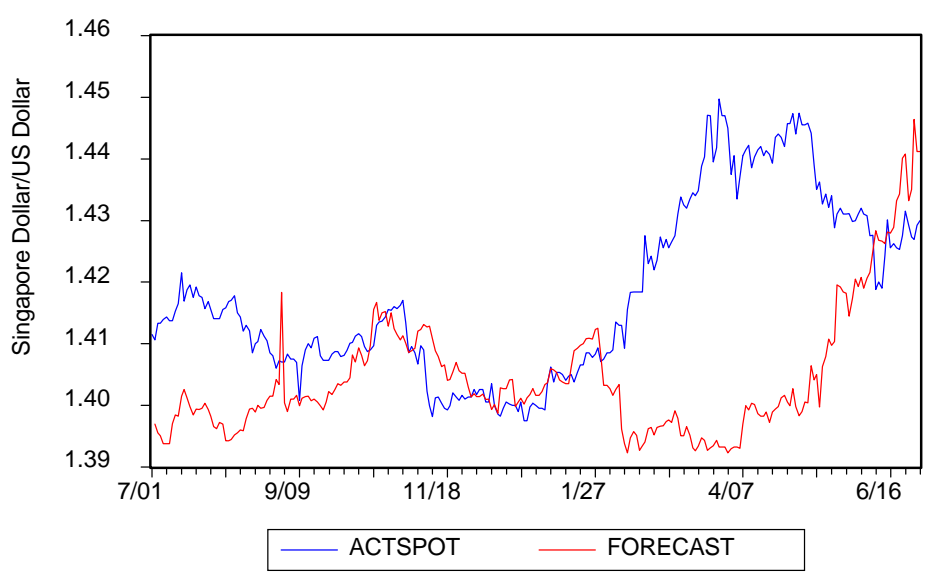

Figure 4e. The Actual and Forecast Spot Rate of Singapore Dollar against US Dollar (1997 - 1998)

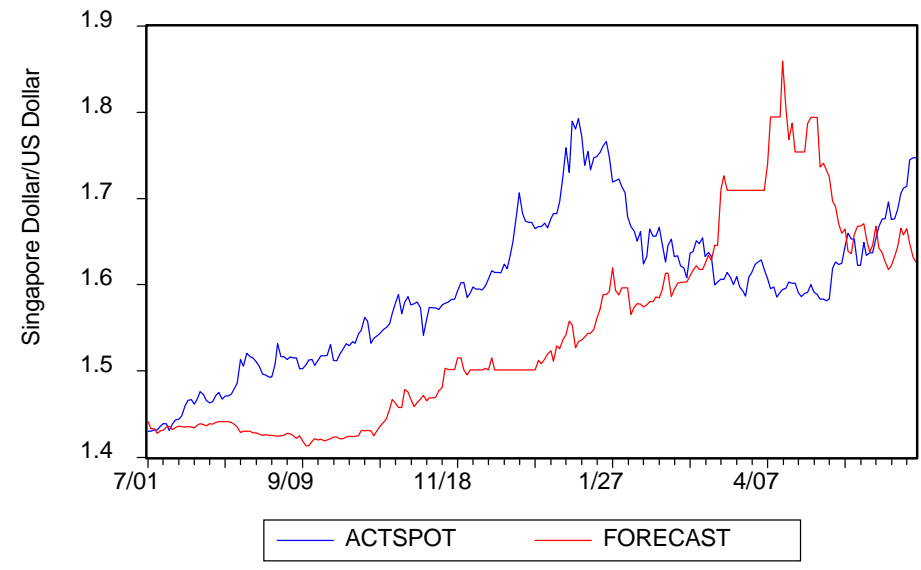


Figure 5c. The Actual and Forecast Spot Rate of Hong Kong Dollar against US Dollar (1996 - 1998)

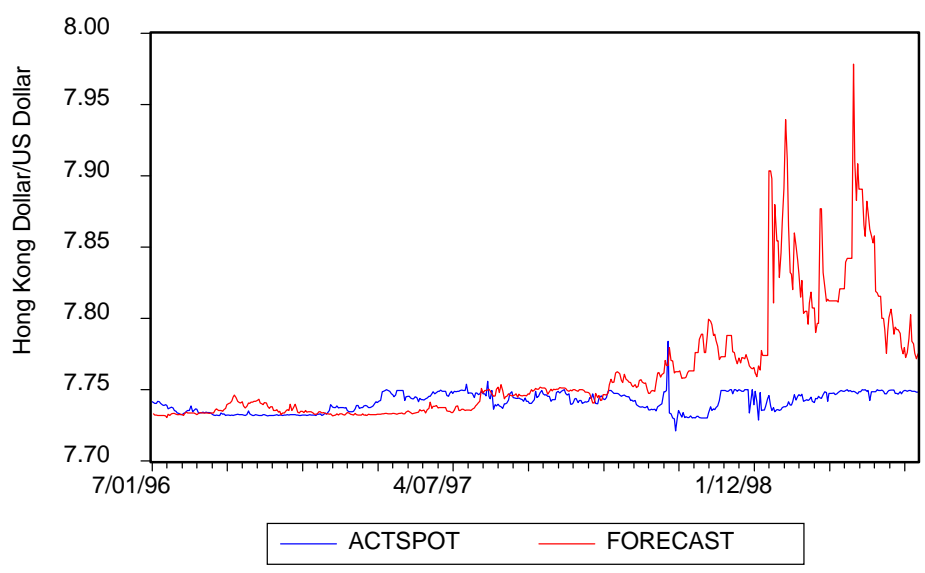

Figure $5 \mathrm{~d}$. The Actual and Forecast Spot Rate of Hong Kong Dollar against US Dollar (1996 - 1997)

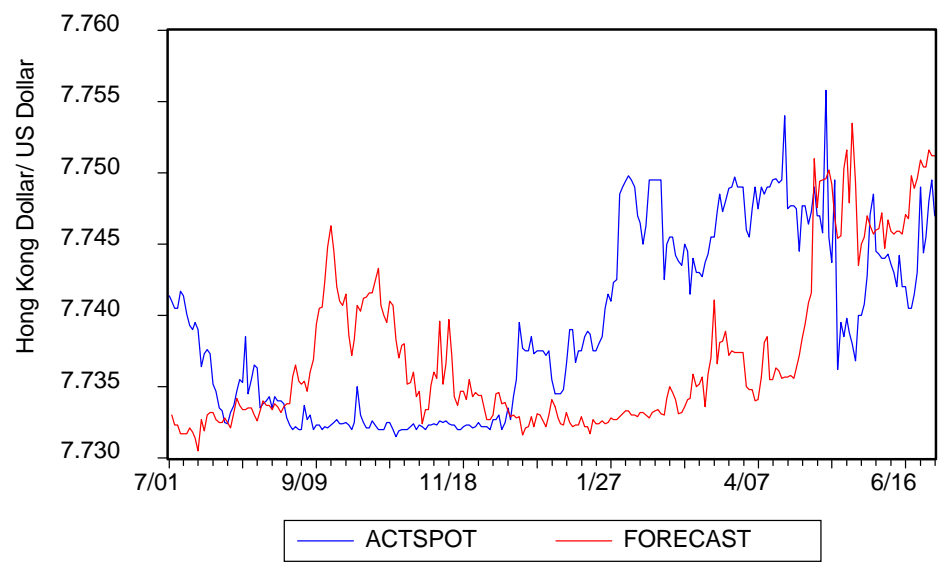

Figure 5e. The Actual and Forecast Spot Rate of Hong Kong Dollar against US Dollar (1997 - 1998)

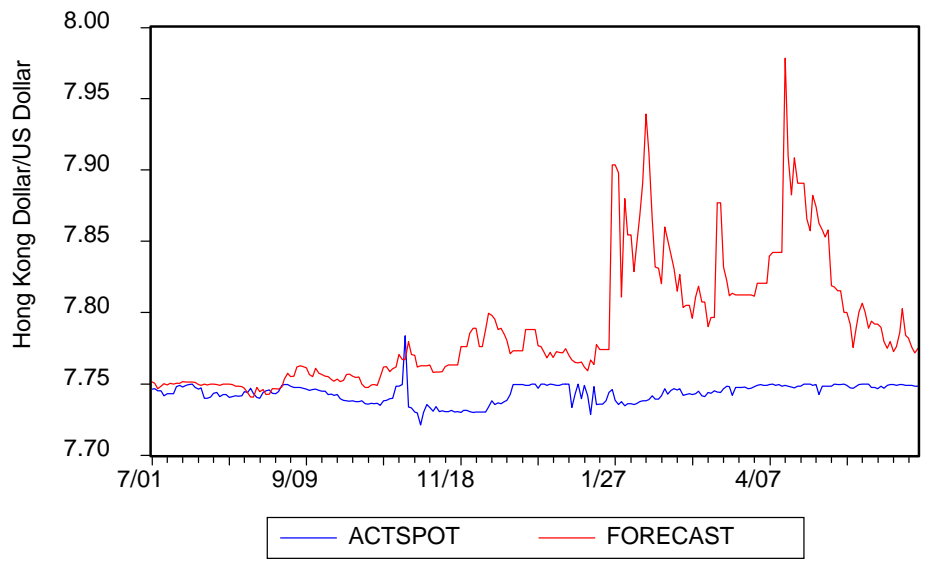


Figure 6c. The Actual and Forecast Spot Rate of Japanese Yen against US Dollar (1996 - 1998)

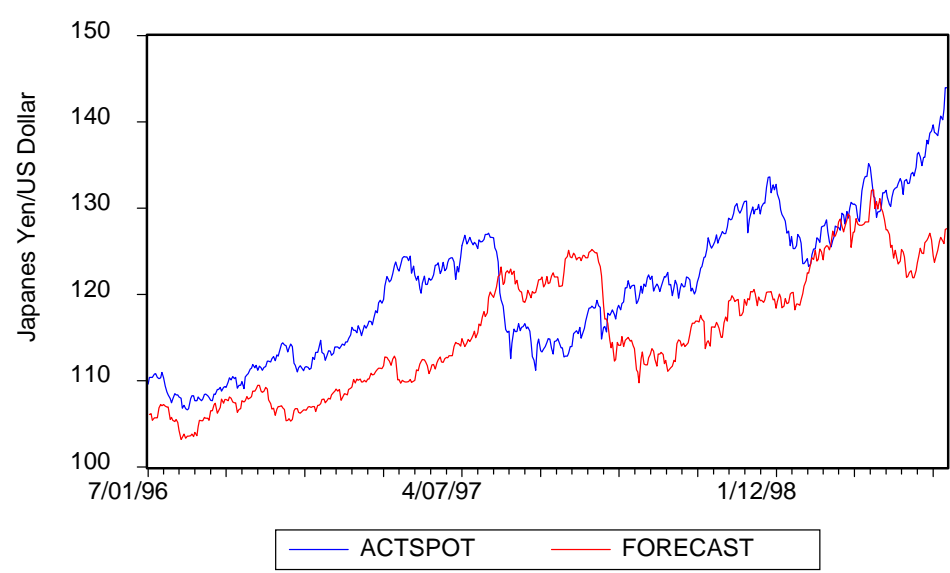

Figure $6 \mathrm{~d}$. The Actual and Forecast Spot Rate of Japanese Yen against US Dollar $(1996$ - 1997)

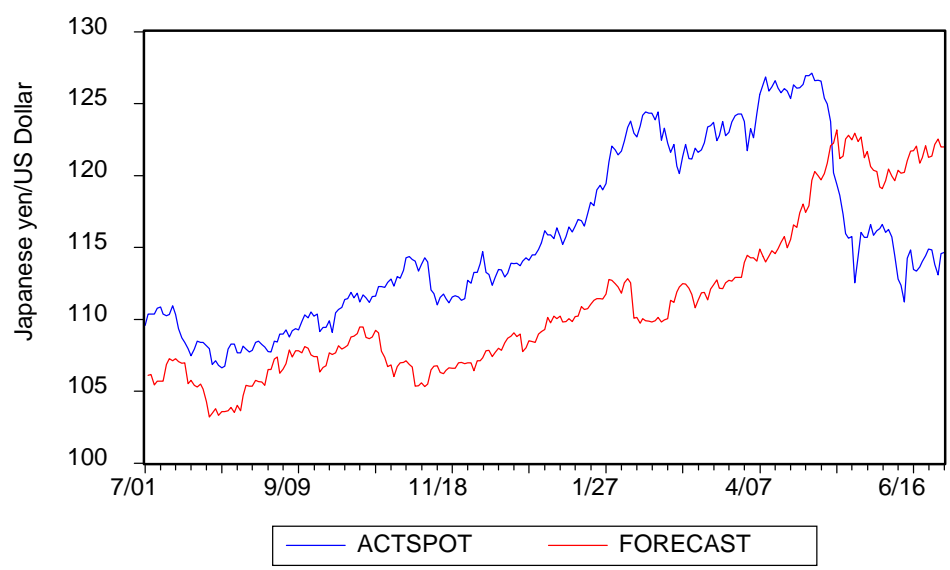

Figure 6e. The Actual and Forecast Spot rate of Japanese Yen against US Dollar (1997 - 1998)

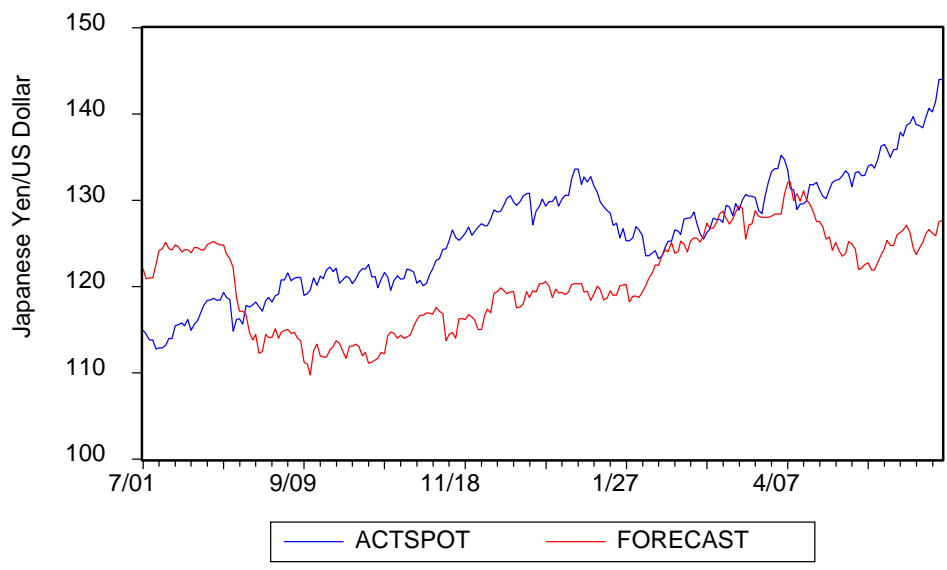




\section{(2) Analisis Kuantitatif}

Hasil unit root analysis sebagaimana dirangkum dalam Tabel 2, mengindikasikan bahwa variabel (series) yang diuji bersifat non stasioner. Oleh karenanya dilakukan uji orde pertama (first difference) untuk merubah trend yang bersifat non stasioner menjadi stasioner. Hasil unit root analysis untuk orde pertama menunjukkan adanya penolakan variableyang non stasioner. Dengan kata lain bahwa hipotesa awal (Ho : terdapat unit root) ditolak atau seluruh rangkaian variabel spot dan forward yang dianalisis terintegrasi pada order pertama I(1) atau bersifat stasioner untuk kelima negarayang diuji (Indonesia, Malaysia, Singapura, Hong Kong dan Jepang).

Berdasarkan persamaan umum untuk Random Walk Hypothesis (RWH), Unbiased Forward rateH ypothesis (UFH) dan CompositeEfficiency Hypothesis (CEH), angkakoefisien dari masing-masing persamaan tersebut dapatterpenuhi untuk mata uang IndonesiaRupiah, Malaysian Ringgit dan Singapore Dollar. Namun demikian hasil uji Engle-Granger pada Tabel 3 menunjukkan bahwa hanya Hong Kong Dollar yang menunjukkan adanya keterkaitan hubungan jangka panjang (kointegrasi) antara nilai Spot dan Forward dengan hasil cukup signifikan ( $\alpha=5 \%$ ). Hal ini terbukti dengan ditolaknya hipotesa awal ( $\mathrm{Ho}=$ tidak ada kointegrasi) untuk mata uang Dollar Hong Kong dimana nilai ADF > Mac Kinnon Critical values. Sementara itu untuk keempat mata uang lainnya (Rupiah, Ringgit, Dollar Singapura, Yen Jepang) menunjukkan bahwa hipotesa awal diterima (tidak terdapat kointegrasi) atau nilai ADF <Mac.Kinnon Critical values.

Hasil uji kointegrasi pada periodeyang sama menggunakan prosedur Johansen (JML method) menunjukkan hasil yang cukup konsisten, meskipun tidak semua uji hipotesis efisiensi pasar berlaku konsep kointegrasi pasar valas. Tabel $\mathbf{4}$ menunjukkan bahwa untuk uji RWH , ternyata hipotesis awal ( $\mathrm{Ho}=$ tidak ada kointegrasi) untuk mata uang Indonesia Rupiah dan Hong Kong Dollar ditolak. Hal ini berarti terdapat kointegrasi yang ditunjukkan dari nilai uji >nilai kritis Sementara untuk uji UFH, hanya Malaysian Ringgit yang ditolak dan untuk uji CEH, Indonesia Rupiah, Malaysia Ringgit dan Singapore Dollar ditolak hipotesis awalnya.

Dari keseluruhan periode analisis (1996 - 1998), hasil uji kointegrasi menunjukkan bahwa hanya Hong Kong Dollar yang menghasilkan fungsi persamaan ECM dengan al pha $<0$ (konstanta negatif) sebagai prayarat adanya pengaruh yang nyata dari fungsi penyesuaian koreksi error. Tabel 5 menunjukkan koefisien untuk persamaan ECM, dimana dari seluruh periode analisis, Hong Kong Dollar memberikan pengaruh yang nyata, khususnya untuk Random Walk Hypothesis dan Unbiased Forward rate Hypothesis.

Hasil analisis diatas membawa pada satu implikasi bahwa keterkaitan jangka panjang antara nilai Spot dan Forward dari suatu mata uang tidak sepenuhnya tercermin dari 
terpenuhinya koefisien dalam persamaan umum dalam hipotesis pasar yang efisien (eficient market hypothesis). Dalam kenyataannya, tidak semua negara di Asia terimbas krisis mata uang yang ditandai dengan devaluasi ataupun pergantian kebijakan nilai tukar.

Hong Kong Dollar, merupakan salah satu mata uang di Asia yang masih dapat bertahan terhadap serangan spekulan dan gejolak nilai tukar yang terjadi selama krisis Asia. Bila kita kaji lebih jauh, ada beberapa faktor kunci mengapa Dolar Hong Kong cukup stabil dalam menghadapi krisis mata uang di A sia. Sistem mata uang yang dikaitkan dengan nilai Dolar Amerika Serikat (Fixed Exchange rate Regim sejak 1Oktober 1983) merupakan kunci utama dalammenghadapi spekulasi valas (dengan dukungan cadangan devisa hampir USD 100 miliar pada akhir tahun 1997). Faktor pendukung lainnya adal ah struktur ekonomi yang kuat (total perdagangan luar negeri senilai 250\% dari GDP), namun fleksible dan efisien (tingkat pengangguran hanya 2\%), disiplin fiskal yang teruji (selalu surplus sekitar $2 \%$ dari GDP) dan didukung oleh transparansi kebijakan pemerintah serta tidak kalah pentingnya adalah struktur lembaga finansial yang modern namun tetap prudent dengan tingkat rata-rata CAR perbankan sekitar $17 \%$.

Indonesia sampai saat ini masih menghadapi beberapa masalah krusial antara lain masalah membengkaknya hutang luar negeri, kegagalan konsep ekonomi yang berbasis pada konglomerasi (monopolistik), kondisi perbankan yang sangat rapuh dengan permodalan yang negatif, non performing loan karena kredit macet dan spread yang negatif serta semakin meningkatnya pol itical risks sehubungan dengan banyaknya kerusuhan sosial akhir-akhir ini, yang kesemuanya bermuara pada tipisnya kepercayaan para investor luar negeri untuk berinvestasi di Indonesia. Dalam menghadapi krisis mata uang, kebijakan pemerintah Indonesia lebih berorientasi ke pasar dengan cara menghapuskan pita intervensi bank sentral sejak 14 Agustus 1997 dengan konsekuensi nilai Rupiah akan mengambang secara bebas sesuai dengan keseimbangan antara permintaan dan penawaran pasar. Titik tertinggi lemahnya nilai tukar Rupiah terhadap US Dollar sempat terjadi pada tanggal 18 Juni 1998 yakni pada tingkat harga Rp16,900 per USD.

Sementaraitu, Pemerintah Malaysia nampaknya lebih condong untuk mengikuti saran Paul Krugman untuk melakukan currency peg policy dalam menghadapi gejolak mata uang Asia. Kebijakan yang efektif diterapkan sejak tanggal 1 September 1998 tersebut adalah menetapkan fixed exchangerateMYR pada tingkat harga 3.8per USD. Sistem nilai tukar tetap tersebut dinilai cukup efektif dalam upaya meredam laju depresiasi MYR yang berlebihan.

Kinerja perekonomian Singapore telah pulih kembali sejal an dengan berkurangnya efek penularan yang sempatmelemahkan matauang SingaporeDollar. Tanda-tanda pulihnya perekonomian Singaporetersebut antara lain tercermin dari gejala turunnya tingkat suku bungajangka pendek, relatif longgarnya kebijakan moneter dan mulai bergairahnya sektor 
riil. Di sisi yang lain, Jepang saat ini juga masih mengalami penurunan kinerja ekonomi sebagai akibat dari rel atif lemahnya sistem perbankan dan lembaga keuangan Jepang serta adanya tekanan dari Amerika Serikat untuk membuka pasar domestiknya untuk barangbarang dari luar negeri. (Tabel 6, Beberapa indikator ekonomi dari 5 negara A sia).

\section{Penutup}

Sebagai kesimpulan dari analisis efisiensi pasar valas diatas, secara umum masih sejalan dengan pembuktian empiris yang telah dilakukan oleh beberapa peneliti terdahulu, namun demikian masih ada beberapa variasi dari penemuan dengan topik kajian yang sama. Hasil anal isis Froot (1990), Hopper (1994) dan Madsen (1996) , yang menyimpulkan adanya inefisiensi pada pasar valas (Spot dan Forward) serta mengindikasikan adanya kemungkinan exploitabl eextra return yang menjurus pada tindakan spekulatif di pasar valas, menarik untuk diteliti lebih dalam lagi pada masa mendatang. Secara metodologis, adanya variasi hasil penelitian tersebut dimungkinkan oleh adanya perbedaan periodesampel yang diuji serta frekuensi data yang dianalisis (hourly, daily, monthly data). Faktor lain yang juga menyebabkan bias adalah metodologi yang digunakan dalam analisis.

Interpretasi terhadap hasil analisis diatas harus dicermati secara hati-hati mengingat eksistensi dari metode pengujian Engle-Granger dan JML ternyatajuga masih memerlukan catatan khusus yang harus dipertimbangkan. Sebagai contoh, meskipun metode Engle Granger sangat mudah dalam implementasinya dan hasil keluarannya (estimasinya) sangat konsisten bila variabelnya terkointegrasi; namun metode ini juga memiliki kelemahan. Kelemahan tersebut antara lain berupa parameter-parameter keseimbangan jangka panjang yang dihasilkan dari metodeini sangat tergantung pada variabel mana yang diambil sebagai en dogenous variable, khususnya bila sampl eyang diambil relatif sedikit. Terlebih lagi, dengan metodeini kemungkinan adanya vektor-vektor yang memiliki kointegrasi ganda (multiple cointegration vectors) dihilangkan.

Hasil analisis kualitatif dan kuantitatif diatas secara umum juga menggambarkan bahwa krisis mata uang Asia telah memberikan implikasi yang cukup signifikan dalam pembentukan nilai tukar pasar valas (Spot dan Forward khususnya) di 5 negarayang diteliti. Beberapa implikasi yang telah terjadi tidak saja terbatas pada implikasi yang bersifat ekonomi moneter seperti perubahan kebijakan pemerintah di bidang nilai tukar, namun juga memiliki implikasi sosial dan politik. Secara spesifik, adanya depresiasi yang berlebihan dalam jangka waktu yang relatif singkat, dapat memperburuk sendi-sendi perekonomian yang sudah berjalan normal, perlunya revisi atas komitmen dan kalkulasi bisnisyang sudah disepakati , menurunnya kredibilitas lembaga pemerintah maupun swasta serta melesetnya proyeksi masa depan bangsa dan negara. Pada gi lirannya kondisi ini akan bermuara pada turunnya peringkat kedaulatan (sovereign rating) yang diberikan oleh lembaga-lembaga internasional. 
Krisis mata uang Asia, bagi Indonesia memberikan implikasi tersendiri. Dalam dua tahun terakhir ini kondisi makro dan mikro ekonomi Indonesia telah terpuruk pada satu krisis nasional yang berkepanjangan. Kondisi ini diperparah dengan adanya krisis sosial politik sehubungan dengan adanya pergantian kepemimpinan pada pertengahan 1997. Perubahan yang terlalu cepat di segala sektor kehidupan telah menimbulkan akibat negatif seperti meningkatnya pengangguran, jumlah penduduk miskin serta tidak berjalannya kehidupan bisnis yang normal dan kondusif bagi pertumbuhan ekonomi dan kesejahteraan masyarakat banyak.

Beberapa hal yang dapat disarankan adalah peningkatan efisiensi di segala sektor sudah selayaknya dilakukan baik di sektor pemerintah maupun sektor swasta. Transparansi kebijakan pemerintah yang berkaitan dengan keberadaan pasar valas dapat dijadikan satu instrumen yang efektif untuk menghindari adanya asymmetric information. A danya transparansi tersebut diharapkan mampu memberikan pemahaman yang cukup menyeluruh kepada para pelaku pasar dan masyarakat luas akan pentingnya makna stabilitas nilai tukar dalam upaya meningkatkan efisiensi pasar yang pada akhirnya bermuara padameningkatnya daya saing ekonomi. Indonesiayang menganutsistem ekonomi terbuka dan devisa bebas serta nilai tukar yang mengambang, kiranya masih memerlukan dukungan Bank Sentral dalam bentuk intervensi yang bertujuan untuk mengurangi gejolak nilai tukar yang berlebihan. Melalui intervensi yang efektif, diharapkan akan tercapai kestabilan dan keseimbangan nilai tukar Rupiah terhadap USDollar yang mampu menjamin kepastian berusaha dan pada akhirnya memberikan kemantapan bagi pengendalian perekonomian secaramenyeluruh. 


\section{Lampiran}

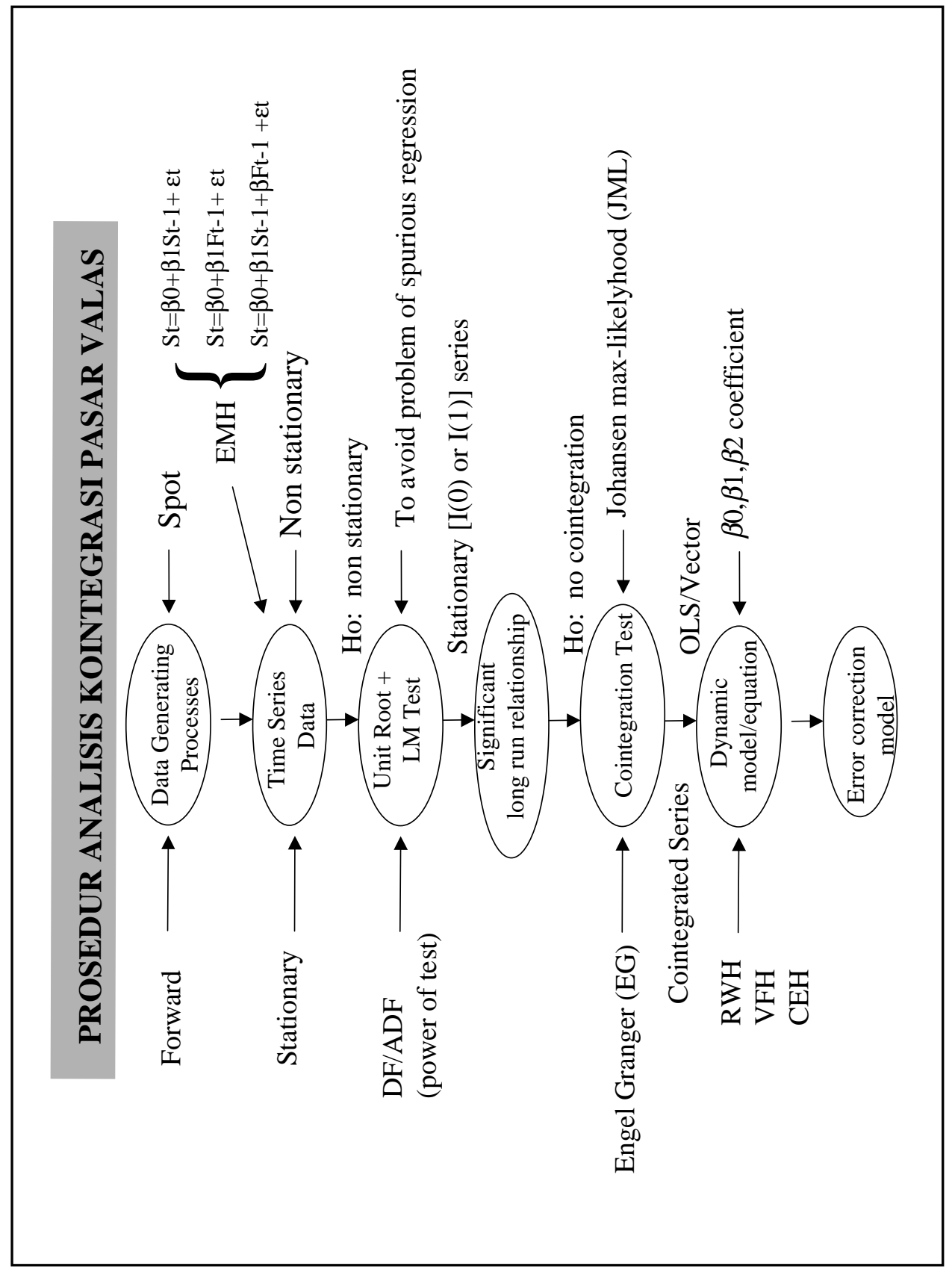


Tabel 2. Unit Root Tests for Logarithm of the Whole Period of Series (1st A pril 1996 - 12th June 1998)

\begin{tabular}{|c|c|c|c|c|c|}
\hline Variables & ADF & DW & $\operatorname{LM}(5)$ & $\mathbf{n}$ & Conclusion \\
\hline \multicolumn{6}{|l|}{ LEVEL } \\
\hline USIDR & 0.5284 & 2.0309 & 4.0105 & 2 & $\mathrm{I}(1)$ \\
\hline USIDR3F & 0.4884 & 1.9940 & 2.6228 & 6 & $\mathrm{I}(1)$ \\
\hline USMALAY & -0.1951 & 2.0167 & 2.4897 & 7 & $\mathrm{I}(1)$ \\
\hline BBMYR3F & -0.0203 & 2.0029 & 1.5769 & 1 & $\mathrm{I}(1)$ \\
\hline USSINGD & 0.389 & 1.999 & 0.9517 & 1 & $\mathrm{I}(1)$ \\
\hline BBSGD3F & 0.0447 & 1.9931 & 2.9544 & 4 & $\mathrm{I}(1)$ \\
\hline USHKDOL & -3.1833 & 2.0123 & 2.2083 & 1 & $\mathrm{I}(1)$ \\
\hline BBHKD3F & -1.8703 & 2.0000 & 0.4471 & 1 & $\mathrm{I}(1)$ \\
\hline USJAPYN & 0.2472 & 1.9989 & 0.0002 & 1 & $\mathrm{I}(1)$ \\
\hline BBJPY3F & 0.1096 & 1.9956 & 0.3429 & 1 & $\mathrm{I}(1)$ \\
\hline \multicolumn{6}{|c|}{ FIRST DIFFERENCE } \\
\hline DUSIDR & $-11.8266^{\star}$ & 1.9984 & 0.0257 & 1 & $\mathrm{I}(0)$ \\
\hline DUSIDR3F & $-11.6399^{\star}$ & 1.9969 & 0.0645 & 1 & $\mathrm{I}(0)$ \\
\hline DUSMALAY & $-11.6241^{*}$ & 2.0123 & 1.5019 & 1 & $\mathrm{I}(0)$ \\
\hline DBBMYR3F & $-10.7129^{\star}$ & 2.0088 & 2.4449 & 2 & $\mathrm{I}(0)$ \\
\hline DUSSINGD & $-10.2952^{\star}$ & 1.9909 & 1.3602 & 1 & $\mathrm{I}(0)$ \\
\hline DBBSGD3F & $-10.1754^{\star}$ & 2.0144 & 0.8359 & 2 & $\mathrm{I}(0)$ \\
\hline DUSHKDOL & $-12.8887^{*}$ & 2.0094 & 2.0008 & 1 & $\mathrm{I}(0)$ \\
\hline DBBHKD3F & $-11.9532^{*}$ & 1.9992 & 0.0209 & 1 & $\mathrm{I}(0)$ \\
\hline DUSJAPYN & $-9.3484^{\star}$ & 2.0001 & 0.0009 & 1 & $\mathrm{I}(0)$ \\
\hline DBBJPY3F & $-9.3634^{\star}$ & 2.0018 & 0.1633 & 1 & $\mathrm{I}(0)$ \\
\hline
\end{tabular}

Note : MacKinnon Critical values for ADF Tests for level and first difference variables

$$
\begin{array}{llll}
\text { Level } 1 \%=-3.4442 & \text { First Differences } 1 \% & =-3.4443^{*} \\
5 \% & =-2.8669 & 5 \% & =-2.8669^{*} * \\
10 \% & =-2.5696 & 10 \% & =-2.5696^{*} *
\end{array}
$$

We use LM test with 5 lags to check serial correlation, $\otimes^{2}(5)$ critical values at $1 \%=15.1 *: 5 \%=11.1^{* *}$;

$10 \%=9.24 * * *$. If $\operatorname{LM}(5)$ is less than Critical values then Ho accepted (no correlation in the residual 
Table 3. Cointegration Tests using the Engle G ranger M ethod for Whole Period of Series (1st A pril 1996-12th June 1998)

\begin{tabular}{|c|c|c|c|c|c|c|}
\hline Hypothesis & Currency & Constant & $\begin{array}{l}\text { Coefficient } \\
\text { of Spot }\end{array}$ & $\begin{array}{l}\text { Coefficient } \\
\text { of Forward }\end{array}$ & $\begin{array}{c}\text { R- } \\
\text { squared }\end{array}$ & ADF \\
\hline \multicolumn{7}{|l|}{ (1).RWH } \\
\hline & USIDR & -0.6966 & 1.1099 & - & 0.7007 & -2.0684 \\
\hline & USMALAY & 0.1126 & 0.9422 & & 0.6964 & -1.8764 \\
\hline & USSINGD & 0.0689 & 0.8705 & & 0.6369 & -1.7146 \\
\hline & USHKDOL & 1.5563 & 0.2396 & & 0.0509 & $-3.0688^{\star \star}$ \\
\hline & USJAPYN & 1.1064 & 0.7737 & & 0.5182 & -1.5555 \\
\hline \multirow[t]{5}{*}{ (2).UFH } & USIDR & -0.4241 & - & 1.0719 & 0.7033 & -2.0507 \\
\hline & USMALAY & 0.1137 & - & 0.9392 & 0.6863 & -1.9318 \\
\hline & USSINGD & 0.1032 & - & 0.9392 & 0.6863 & -1.725 \\
\hline & USHKDOL & 1.9511 & - & 0.0466 & 0.6133 & $-3.2598^{\text {kt }}$ \\
\hline & USJAPYN & 1.1122 & - & 0.7746 & 0.5182 & -1.5618 \\
\hline \multirow[t]{5}{*}{ (3).CEH } & USIDR & -0.3698 & -0.201 & 1.2654 & 0.7034 & -2.0401 \\
\hline & USMALAY & 0.1195 & 1.6791 & -0.742 & 0.6989 & -2.0379 \\
\hline & USSINGD & -0.9215 & 3.7105 & -2.6179 & 0.6709 & -2.1024 \\
\hline & USHKDOL & 1.5278 & 0.2105 & 0.0429 & 0.1129 & $-3.2979^{\star \star}$ \\
\hline & USJAPYN & 1.1079 & 0.3629 & 0.4115 & 0.5164 & -1.5567 \\
\hline
\end{tabular}

Note :

MacKinnon Critical Values for ADF Tests $1 \%=-3.4456^{*}: 5 \%=-2.8676^{* *}: 10 \%=-2.5700^{* * *}$

RWH $=$ Random Walk Hypothesis

$\mathrm{S}_{\mathrm{t}+1}=\beta_{0}+\beta_{1} \mathrm{~S}_{\mathrm{t}}+\varepsilon_{\mathrm{t}+1}$

UFH $=$ Unbiased Forward Rate Hypothesis

$S_{t+1}=\beta_{0}+\beta_{1} F_{t}+\varepsilon_{t+1}$

$\mathrm{CEH}=$ Composite Efficiency Hypothesis

$\mathrm{S}_{\mathrm{t}+1}=\beta_{0}+\beta_{1} \mathrm{~S}_{\mathrm{t}}+\beta_{1} \mathrm{~F}_{\mathrm{t}}+\varepsilon_{\mathrm{t}+1}$ 
Table 4. Cointegration Tests using Johansen's M aximum Likelihood for the whole period of series (1st A pril 1996- 12th June 1998)

\begin{tabular}{|c|c|c|c|c|c|}
\hline Hypothesis & $\begin{array}{l}\text { Ho } \\
\text { H1 }\end{array}$ & $\begin{array}{l}r=0 \\
r=1\end{array}$ & $\begin{array}{l}r<=1 \\
r=2\end{array}$ & $\begin{array}{c}r<=2 \\
r=3\end{array}$ & $\begin{array}{c}\text { No } \\
\text { Vectors (r) }\end{array}$ \\
\hline \multirow[t]{5}{*}{ (1).RWH } & IDR & $16.4012^{\star \star}$ & 2.0985 & & 1 \\
\hline & MALAY & 11.1782 & 0.0708 & & 1 \\
\hline & SINGD & 14.6189 & 1.1414 & & 1 \\
\hline & HKDOL & $16.3856^{\star \star}$ & $5.9975^{\star}$ & & 2 \\
\hline & JAPYN & 9.7135 & 0.2871 & & 1 \\
\hline \multirow[t]{2}{*}{ Critical values } & $5 \%\left(^{* *}\right)$ & 15.41 & 3.76 & & \\
\hline & $1 \%\left({ }^{\star}\right)$ & 20.04 & 6.65 & & \\
\hline \multirow[t]{5}{*}{ (2).UFH } & IDR & 14.7247 & 1.3957 & & 0 \\
\hline & MALAY & $16.3028^{\star \star}$ & 0.1079 & & 1 \\
\hline & SINGD & 13.4637 & 1.0147 & & 0 \\
\hline & HKDOL & 9.2296 & 1.6354 & & 0 \\
\hline & JAPYN & 10.0739 & 0.3554 & & 0 \\
\hline \multirow[t]{2}{*}{ Critical values } & $5 \%(* *)$ & 15.41 & 3.76 & & \\
\hline & $1 \%\left(^{\star}\right)$ & 20.04 & 6.65 & & \\
\hline \multirow[t]{5}{*}{ (3).CEH } & IDR & $32.7699^{\star *}$ & 13.2738 & 0.0222 & 1 \\
\hline & MALAY & $41.4758^{\star}$ & 13.0305 & 0.9609 & 1 \\
\hline & SINGD & $30.457^{\star \star}$ & 11.8067 & 1.3428 & 1 \\
\hline & HKDOL & 18.1256 & 9.2699 & 0.9863 & 0 \\
\hline & JAPYN & 20.6029 & 7.9356 & 0.1505 & 0 \\
\hline \multirow[t]{2}{*}{ Critical values } & $5 \%\left({ }^{* \star}\right)$ & 29.68 & 15.41 & 3.76 & \\
\hline & $1 \%\left(^{\star}\right)$ & 35.65 & 20.04 & 6.65 & \\
\hline
\end{tabular}


Table 5. Error Correction M odels for the Spot Rates

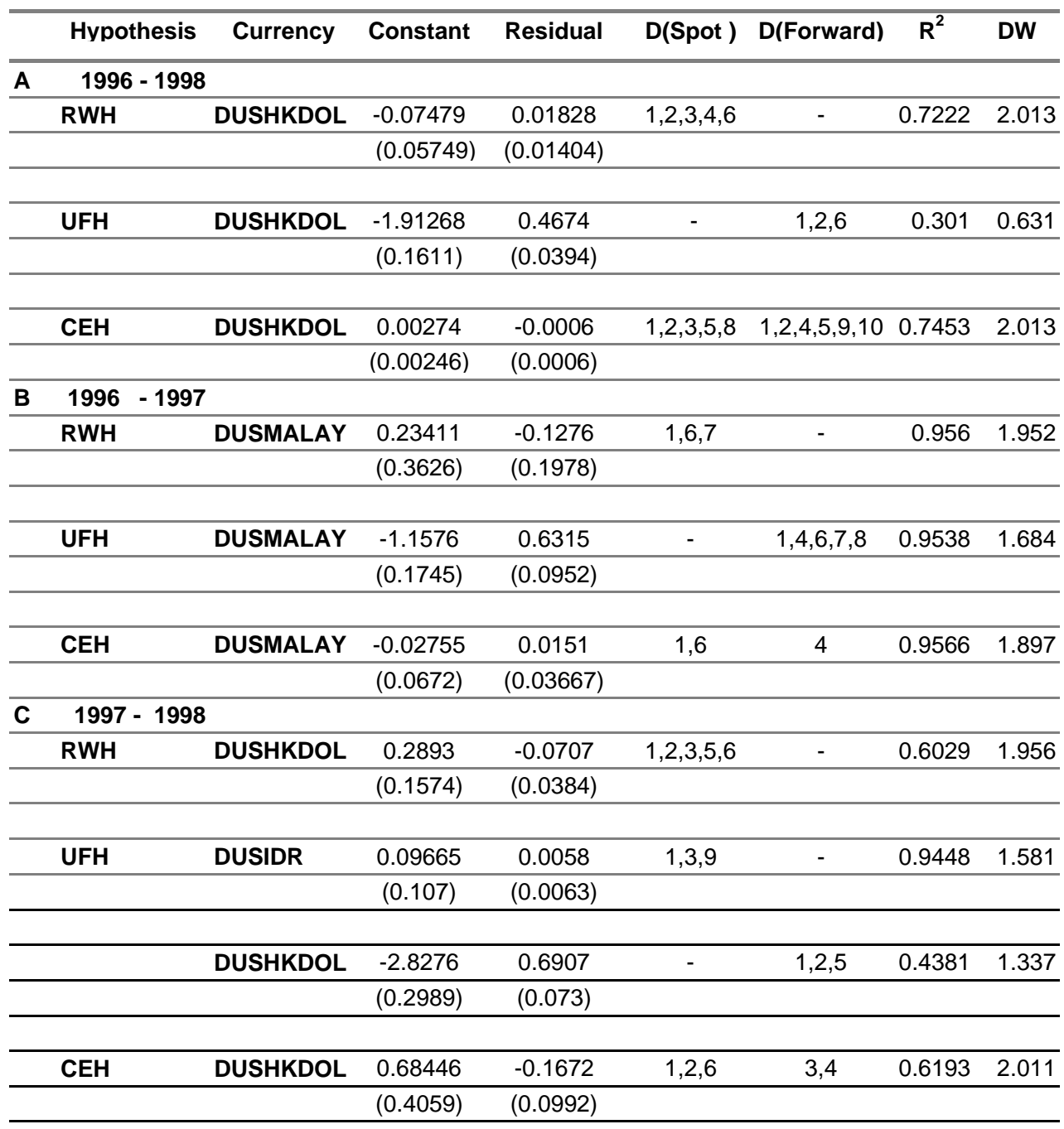

Note :

1. Figures in parenthesis denote standard errors of coefficients.

2. Numbers in $\mathrm{D}$ (Spot) and $\mathrm{D}$ (Forward) column are the numbers of lag length of first difference of the variables which are statistically significant.

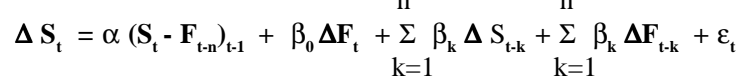


Tabel 6. Beberapa Indikator Ekonomi Lima N egara A sia

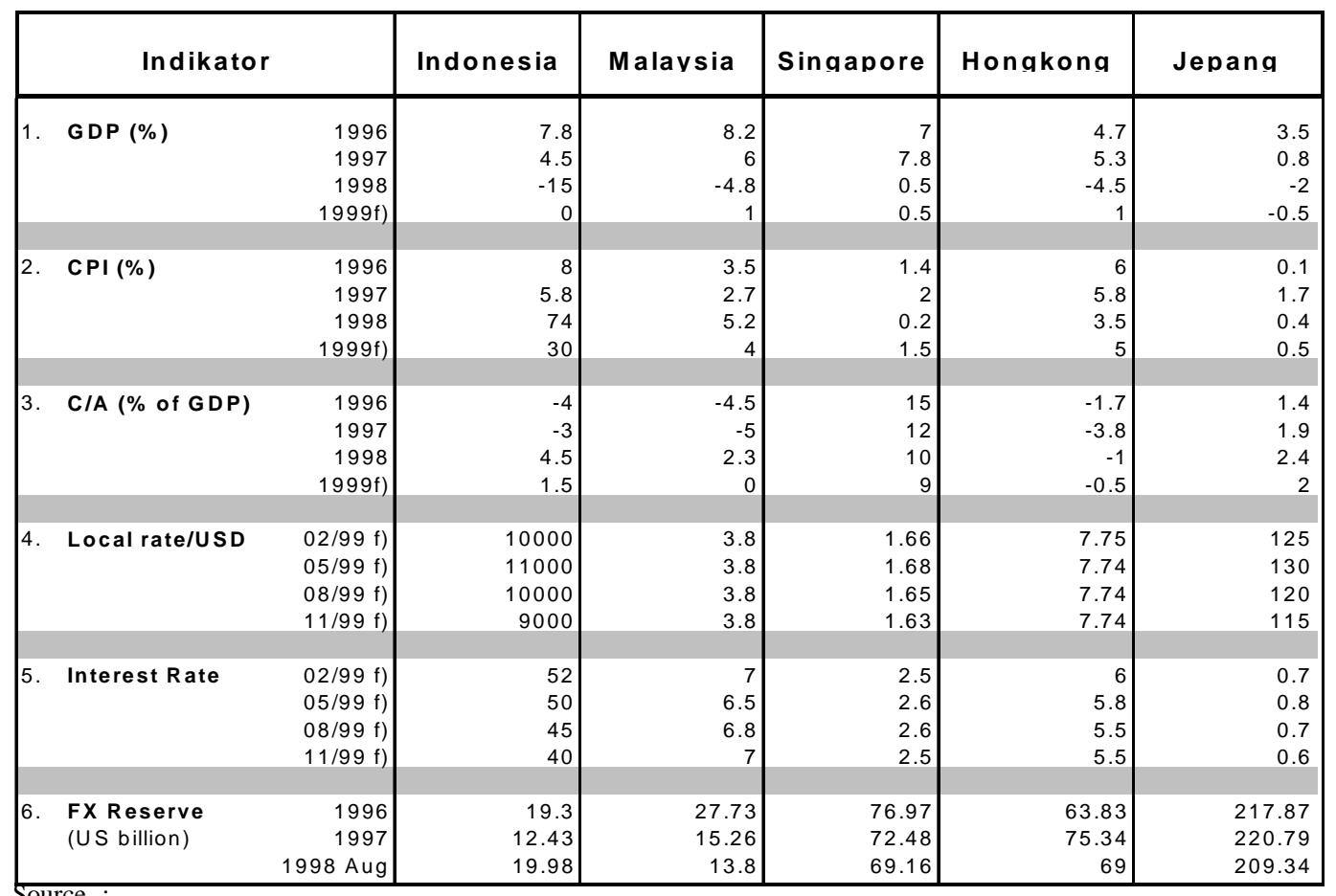

- Bank of America, Asia Prospect 1999 - 2000, December 1998

- Warburg Dillon Read, Asian Adviser, November 1998

f) forecast

\section{D aftar Pustaka}

A beysekera S.P , Trutle H.J.(1995), Long Run Relations in Exchange M arkets : A Test for Cover ed Inter est Parity. The Journal of Financial research. Vol XVIII, N o,4 pages 431-447.

Alexakis, P and Apergis,N. (1996), ARCH Effects and Cointegration : Is the Foreign Exchange $\mathrm{M}$ arket Efficient?. Journal of Banking and Finance 20.p.687-697. N orth Holland.

Baillie, R.T. and McMahon, P.C. (1994), The Foreign Exchange M arket : Theory and Econometric Evidence. CambridgeUniversity Press, Cambridge.

(1996), Central Bank Survey of Foreign Exchange and Derivatives M arket Activity. Bank for International Settlement(BIS), Basle.Switzerland.

Camdessus, Michael (1998), Is the A sian Crisis 0 ver? (Speech , A pril 2), International Monetary Fund. Washington, D.C.

(1997), The Five Fold Impact of the A sian Crisis, Chase Research , Chase Securities Inc. November 13th, N ew York. 
Cavaglia, S and Wolf C.C.P. (1996), A N ote on the D eterminants of U nexpected Exchange R ate M ovements, Journal of Banking and Finance 20,p.179-188, Elsevier. North, Holland.

Chiang, T. (1986), Empirical A nalysis on the Predictors of Future Spot Rate, Journal of Financial Research, Vol.9 No.2, June pp 153- 62.

Copeland, L.S. (1991), Cointegration Tests with D aily Exchange RateD ata, Oxford Bulletin of Economic and Statistics, 53, p2.

Dickey, D.A and W.A. Fuller (1979), D istribution of the estimators for autoregressive time series with a unit root, Journal of the A merican Statistical Association,74 p.427-31.

Dickey, D.A. and W.A. Fuller (1981), Likelihood ratio statistics for autoregressive with a unit root, Econometrica, 49,p.1057-72.

Diebold, F.X. et al.(1994), On Cointegration and Exchange rate D ynamics, The Journal of FinanceVol XLIX No.2.June.

Eiteman, et al. (1995), M ultinational Business Finance, Addison Wesley. 7th Edition, Reading, MA.

Engle, R.F. and C.W.J. Granger (1987), Cointegration and Error Correction :Representation, Estimation and Testing, Econometrica,55 p251-76.

Engle, R.F. and B.S.Yoo (1991), Cointegrated Economic Time Series: An O verview with new results, in R.F. Engleand C.W.J. Granger (Eds).Long Run Relationships, Oxford Univeristy Press, p.237-66.

Fama, E. (1970), Efficient Capital M arket : A R eview of Theory and Empirical W ork, Journal of Finance 25. May.pp 383-417.

Fisher, Stanley. (1998), The A sian Crisis, the IM F and the Japanese Economy, (Speech : A pril 8). International Monetary Fund. Tokyo.

Frankel. Jeffry A.(1993), On ExchangeR ate, Massachusetts Institute of Technology.

Frankel,J and Froot, K. (1987), Short term and long term expectations of theyen-dollar exchange rate: evidencefrom survey data, Journal of Japaneseand International Economies,1,p.139-61.

Frankel,J and Froot,K. 91987), U sing Survey D ata to T est Standard Propositions on Exchange rateExpectations, American Economic Review, p.133-53.

Froot, K and Thaler,H, (1990), A nomalies : Foreign Exchange, Journal of Economic Perspectives,3,p.179-92.

Harris,R.I.D. (1995), U sing Cointegration A nalysis in Econometric M odelling, PrenticeHall. London.

Hopper, G.P. (1994), Is the Foreign Exchange M arket Inefficient?, Federal Reserve Bank of Philadelphia, Business Review, May/ June.p.17-27. 
Johansen, S. and K. Juselius (1992), Testing Structural hypotheses in a multivariate cointegration analysis of the PPP and U IP for U K, Journal of Economeetrics,53. p.211-44.

Krugman, Paul. (1997), Pop Internationalism, MIT Press, Cambridge, MA . , Bottom Line, The Banker, March 1998.

Levi, Maurice. (1996), International Finance, Mc.Graw Hill Inc, New York . 3rd Edition.

MacDonald,R. and Torrance, T.S.(1990), Expectation formation and risk in four foreign exchangemarkets, Oxford Economic papers, 42 p.544-61.

Maddala, (1992), Introduction to E conometrics, PrenticeH all, New Jersey. 2nd Edition.

Madsen, E.S. (1996), Inefficiency of Foreign Exchange M arkets and Expectations : Survey Evidence, Canadian Journal of A pplied Economic, 28 p.397-403.

Melvin, Michael.(1995), International M oney and Finance, Harper Collin College Publisher. 4th Edition, New York, NY.

Naisbitt,John. (1996), M egatrends A sia, NicholasBrealey Publishing Ltd, 2nd Edition, ～London

N gama, Y.L. (1990), Risk Premia and the Efficiency of the Spot and the Forward Foreign Exchange $M$ arket, Thesis, University of Birmingham, Birmigham.UK.

Plummer, Tony.(1998), Forecasting Financial M arkets, Kogan Page 3rd Edition, London, UK.

Rosenberg, Michael. (1996), Currency Forecasting, Irwin Publishing Co, Chicago..

Sachs, Jeffrey D. (1998), Fixing theIM F R emedy, TheBanker. February .p.16-18, London.

Samuelson,P.A and W.D. Nordhaus.(1985), Economics, 12th edition, McGraw Hill, New York.

Solnik, Bruno.(1995), International Investment, Addison Wesley. 3rd Ed. Reading. MA.

Soros, G and Gidden, A.(1997), Beyond Chaos and D ogma, New Statesman, 31 October.

Stein, J.L and Paladino, G.(1998), Recent D evelopments in International Finance; A Guideto R esearch, Journal of Banking and Finance, 21 p.1685-1720, El sevier.North, Holland.

Stein,J.L. etal (1997), Fundamental D eterminants of ExchangeR ates, Clarendon Press, Oxford, UK.

Throop, A.W. (1994), International Financial M arket Integration and Linkages of $\mathrm{N}$ ational Interest Rates, Federal Reservebank of San Francisco Economic Review, N o.3.

Tucker, Alan J, et al. (1991), International Financial M arket, West Publishing Co. St. Paul .

Warner, Alison. (1998), A sia Fights to Survive, TheBanker, February p. 25- 27.

(1993), TheE ast A sian M iracle, TheWorld Bank-Policy Research Department, Oxford University Press, New York. 